Prepared for the U.S. Department of Energy

under Contract DE-AC05-76RL01830

\title{
Technetium Immobilization Forms Literature Survey
}

JH Westsik, Jr.

KJ Cantrell

RJ Serne

NP Qafoku

May 2014

\section{Pacific Northwest}

NATIONAL LABORATORY

Proudly Operated by Battelle Since 1965 


\title{
DISCLAIMER
}

This report was prepared as an account of work sponsored by an agency of the United States Government. Neither the United States Government nor any agency thereof, nor Battelle Memorial Institute, nor any of their employees, makes any warranty, express or implied, or assumes any legal liability or responsibility for the accuracy, completeness, or usefulness of any information, apparatus, product, or process disclosed, or represents that its use would not infringe privately owned rights. Reference herein to any specific commercial product, process, or service by trade name, trademark, manufacturer, or otherwise does not necessarily constitute or imply its endorsement, recommendation, or favoring by the United States Government or any agency thereof, or Battelle Memorial Institute. The views and opinions of authors expressed herein do not necessarily state or reflect those of the United States Government or any agency thereof.

\author{
PACIFIC NORTHWEST NATIONAL LABORATORY \\ operated by \\ BATTELLE \\ for the \\ UNITED STATES DEPARTMENT OF ENERGY \\ under Contract DE-AC05-76RL01830
}

Printed in the United States of America
Available to DOE and DOE contractors from the
Office of Scientific and Technical Information,
P.O. Box 62, Oak Ridge, TN 37831-0062;
ph: (865) 576-8401
fax: $(865) 576-5728$
email: reports@adonis.osti.gov
Available to the public from the National Technical Information Service
5301 Shawnee Rd., Alexandria, VA 22312
ph: (800) 553-NTIS (6847)
email: orders $a$ ntis.gov <http://www.ntis.gov/about/form.aspx >
Online ordering: http://www.ntis.gov

This document was printed on recycled paper. 


\section{Technetium Immobilization Forms Literature Survey}

JH Westsik, Jr.

KJ Cantrell

RJ Serne

NP Qafoku

May 2014

Prepared for

the U.S. Department of Energy

under Contract DE-AC05-76RL01830

Pacific Northwest National Laboratory

Richland, Washington 99352 



\section{Executive Summary}

Of the many radionuclides and contaminants in the tank wastes stored at the Hanford Site, technetium-99 $\left({ }^{99} \mathrm{Tc}\right)$ is one of the most challenging to effectively immobilize in a waste form for ultimate disposal. Within the Hanford Tank Waste Treatment and Immobilization Plant, the Tc will partition between both the high-level waste (HLW) and low-activity waste (LAW) fractions of the tank waste. The HLW fraction will be converted to a glass waste form in the HLW vitrification facility and the LAW fraction will be converted to another glass waste form in the LAW vitrification facility. In both vitrification facilities, the Tc is incorporated into the glass waste form but a significant fraction of the Tc volatilizes at the high glass-melting temperatures and is captured in the off-gas treatment systems at both facilities. The aqueous off-gas condensate solution containing the volatilized Tc is recycled and is added to the LAW glass melter feed. This recycle process is effective in increasing the loading of Tc in the LAW glass but it also disproportionately increases the sulfur and halides in the LAW melter feed, which increases both the amount of LAW glass and either the duration of the LAW vitrification mission or the required supplemental LAW treatment capacity.

One option being considered to address this issue is to remove the Tc at one of several possible points within the tank waste processing flowsheet so that the LAW melter off-gas condensates do not need to be recycled. The separated Tc must then be dispositioned in a manner such that it can be safely disposed. One option would be to put the Tc in a waste form specifically designed to immobilize the Tc. This literature survey was conducted to identify candidate waste forms for the separated Tc waste stream.

For the purposes of discussion, the Tc waste-form alternatives are divided into two categories. The first category includes waste forms for solidification of multiple components in a waste stream. Included are borosilicate and iron phosphate glasses, cementitious grouts, geopolymers, phosphate-bonded ceramics, the fluidized bed steam reforming aluminosilicate waste form, and the crystalline ceramic Synroc waste form. The second category includes waste forms specifically designed to immobilize Tc. Included are iron-technetium oxides, metal alloys, technetium oxides, silicate minerals, titanates, sulfides, phosphates, layered double hydroxides, and sulfur-based aerogels. 



\section{Acronyms and Abbreviations}

\begin{tabular}{|c|c|}
\hline BFS & blast furnace slag \\
\hline DOE & U.S. Department of Energy \\
\hline Eh & oxidation-reduction potential \\
\hline EPA & U.S. Environmental Protection Agency \\
\hline ETF & Effluent Treatment Facility \\
\hline EXAFS & extended X-ray absorption fine structure \\
\hline FBSR & fluidized bed steam reformer \\
\hline HEPA & high-efficiency particulate air \\
\hline HIP & hot isostatic pressing \\
\hline HLW & high-level waste \\
\hline HTWOS & Hanford Tank Waste Operations Simulator \\
\hline IDF & Integrated Disposal Facility \\
\hline ILAW & immobilized low-activity waste \\
\hline INL & Idaho National Laboratory \\
\hline LAW & low-activity waste \\
\hline LDH & layered double hydroxide \\
\hline PCT & Product Consistency Test \\
\hline PNNL & Pacific Northwest National Laboratory \\
\hline PUF & pressurized unsaturated flow (test) \\
\hline RCRA & Resource Conservation and Recovery Act \\
\hline SBS & submerged bed scrubber \\
\hline SPFT & single-pass flow-through (test) \\
\hline SPS & spark plasma sintering \\
\hline SRNL & Savannah River National Laboratory \\
\hline SRS & Savannah River Site \\
\hline SS-15Zr & stainless steel - $15 \mathrm{wt} \%$ zirconium alloy \\
\hline TCLP & Toxicity Characteristic Leaching Procedure \\
\hline TRUEX & TRansUranium EXtraction \\
\hline WESP & wet electrostatic precipitators \\
\hline WTP & Hanford Tank Waste Treatment and Immobilization Plant \\
\hline XANES & X-ray absorption near-edge structure \\
\hline
\end{tabular}




\section{Units of Measure}

$\begin{array}{ll}{ }^{\circ} \mathrm{C} & \text { temperature in degrees Celsius }\left[\mathrm{T}\left({ }^{\circ} \mathrm{C}\right)=\mathrm{T}(\mathrm{K})-273.15\right] \\ \mathrm{cm} & \text { centimeter } \\ \mathrm{d} & \text { day } \\ \mathrm{g} & \text { gram } \\ \mathrm{K} & \text { temperature in kelvins } \\ \mathrm{M} & \text { molarity, mole/Liter } \\ \mathrm{mL} & \text { milliliter } \\ \mathrm{mol} & \text { mole } \\ \mathrm{MPa} & \text { megapascals } \\ \mathrm{MWd} / \mathrm{t} & \text { megawatt days per ton } \\ \mathrm{nm} & \text { nanometer } \\ \mathrm{pm} & \text { picometer } \\ \mathrm{ppm} & \text { parts per million } \\ \mathrm{s} & \text { second } \\ \mathrm{wt} \% & \text { weight percent } \\ \mathrm{yr} & \text { year }\end{array}$




\section{Contents}

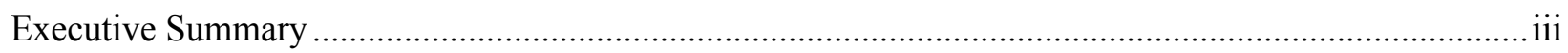

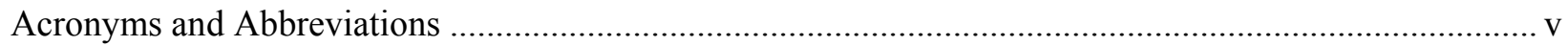

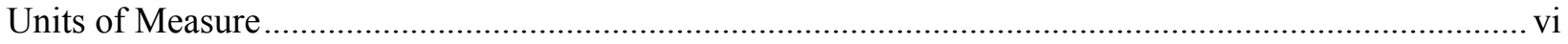

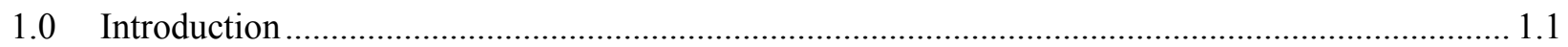

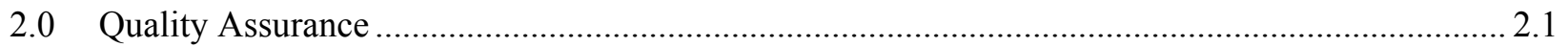

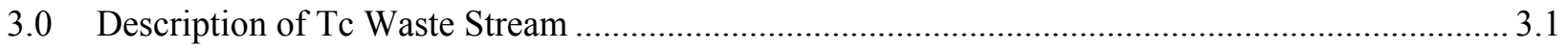

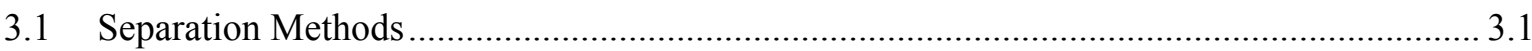

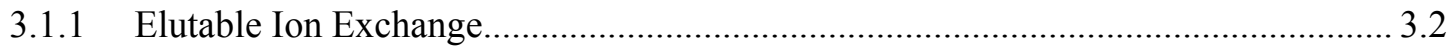

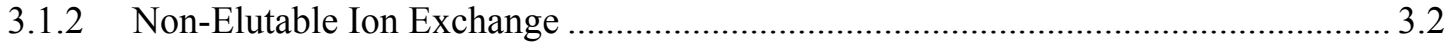

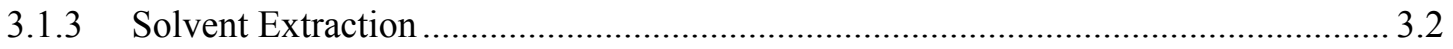

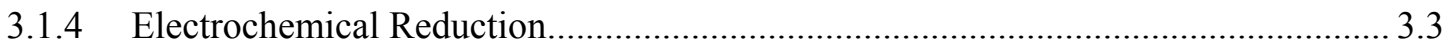

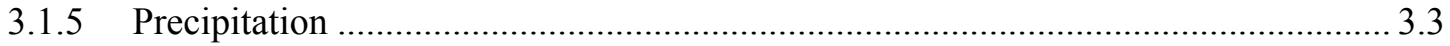

3.2 Nominal Tc Waste Stream Compositions ..................................................................... 3.3

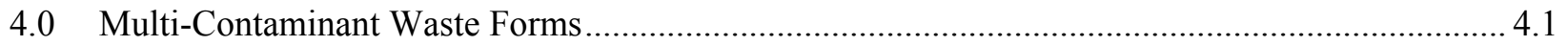

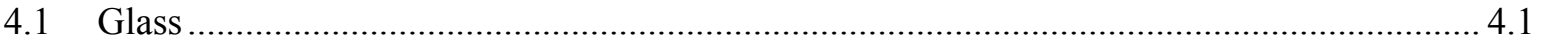

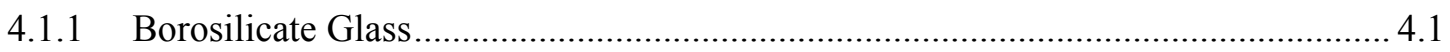

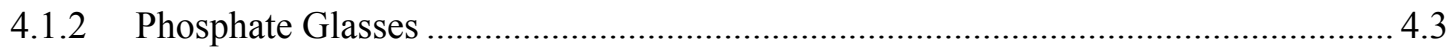

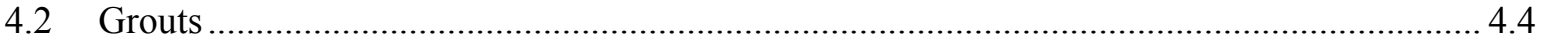

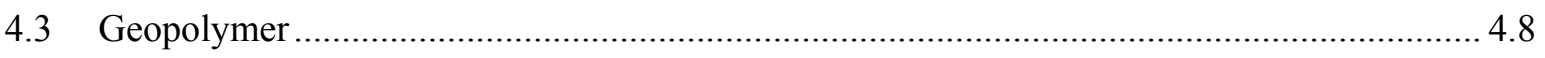

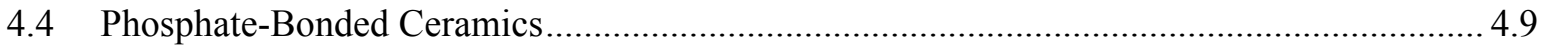

4.5 Fluidized Bed Steam Reforming Aluminosilicate........................................................ 4.10

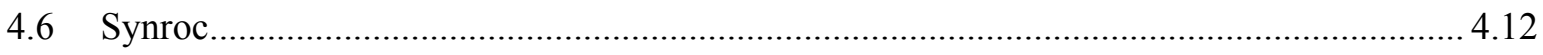

5.0 Technetium-Specific Immobilization Methods........................................................................ 5.1

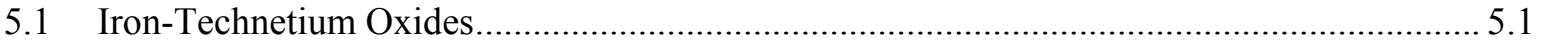

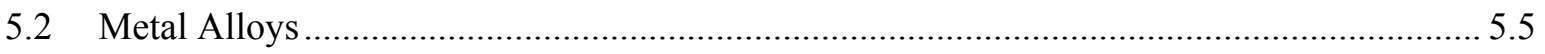

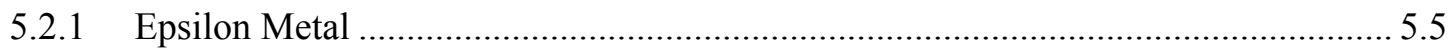

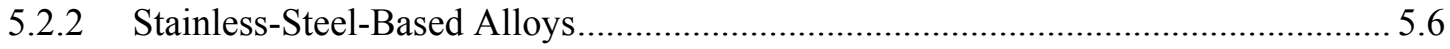

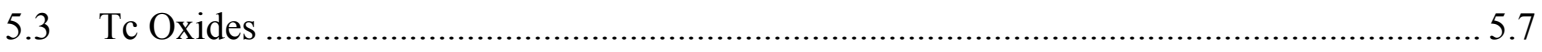

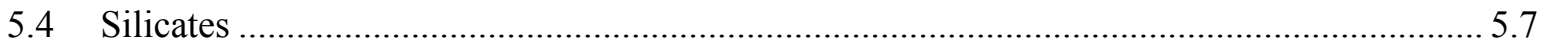

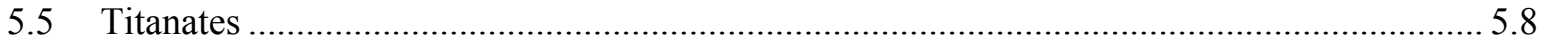

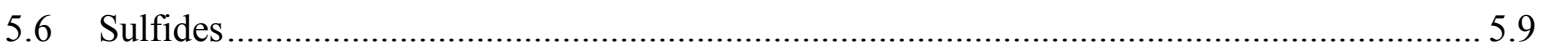

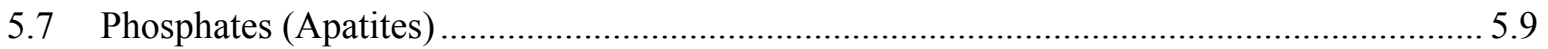

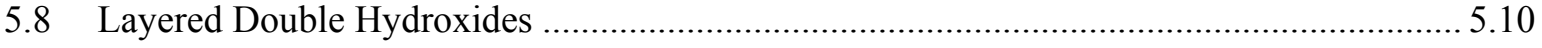

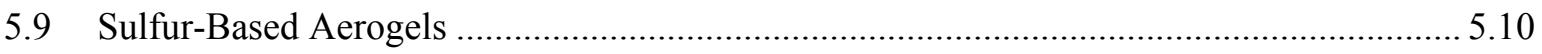

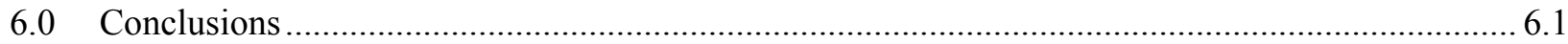

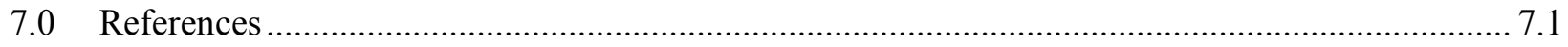




\section{Tables}

3.1. Concentrations of Tc Eluate Streams After Technetium Separations ............................................ 3.4

3.2. Tc Eluate Concentrations from Hanford Tank Waste Samples ..................................................... 3.5

4.1. Example LAW Glass Compositions for Hanford Tank Wastes .................................................... 4.2

4.2. Nominal Compositions of LAW Iron Phosphate Glasses ........................................................... 4.4

5.1. Crystal Radii and Coordination Numbers for Iron, Rhenium, and Technetium ............................ 5.2

5.2. Compositions Used in Testing of Epsilon Metal as a Waste Form .............................................. 5.5

5.3. Technetium Uptake by Sulfur-Based Aerogels....................................................................... 5.11

6.1. Comparison of Advantages and Disadvantages of Tc-Specific Waste Forms ............................... 6.2 


\subsection{Introduction}

More than 56 million gallons of radioactive and hazardous waste are stored in 177 underground storage tanks at the U.S. Department of Energy's (DOE's) Hanford Site in southeastern Washington State. The Hanford Tank Waste Treatment and Immobilization Plant (WTP) is being constructed to treat the wastes and immobilize them in glass waste forms. The WTP includes a pretreatment facility to separate the wastes into a small volume of high-level waste (HLW) containing most of the radioactivity and a larger volume of low-activity waste (LAW) containing most of the nonradioactive chemicals. The HLW will be converted to glass in the HLW vitrification facility for ultimate disposal at an offsite federal repository. At least a portion $(\sim 35 \%)$ of the LAW will be converted to glass in the LAW vitrification facility and will be disposed of onsite at the Integrated Disposal Facility (IDF). Supplemental LAW treatment technologies such as a second LAW vitrification facility; Cast Stone, a low temperature cementitious waste form; and bulk-vitrification are being considered to provide the additional LAW immobilization capacity needed.

Technetium (Tc) is one of the most difficult contaminants in the waste to address because of its complex chemical behavior in tank waste, limited incorporation into glass at the high temperatures of the vitrification process, and high mobility in subsurface environments of the IDF. Approximately 32,600 curies of technetium-99 $\left({ }^{99} \mathrm{Tc}\right)$ were produced at the Hanford Site (Serne and Rapko 2014). Of this, a small amount either has been released to cribs or has leaked from the single-shell tanks $(\sim 700 \mathrm{Ci})$, and up to $7000 \mathrm{Ci}$ was shipped offsite inadvertently with reprocessed uranium destined for purification and re-enrichment. The balance (26,500 Ci, Robbins and May 2013) remains in the Hanford tank wastes and must be dispositioned in approved waste forms. Within the pretreatment facility, the soluble Tc is expected to partition to the LAW stream $(1,563 \mathrm{~kg})$ and a smaller, insoluble fraction of the Tc $(86 \mathrm{~kg})$ is expected to partition to the HLW stream.

Technetium is problematic in LAW due to its long half-life (213,000 years), complex redox chemistry, solubility, and volatility at high temperatures. During the glass melting process, a fraction of the Tc volatilizes from the glass melter and is captured in the off-gas treatment system ( 37 to $82 \%$ ). The off-gas condensates are recycled back through pretreatment and to the LAW and supplemental LAW feed in order to increase the overall retention of Tc in the LAW glass. A side impact of this off-gas recycle is to disproportionately increase the sulfur and halides in the LAW and supplemental LAW feed and thereby increase the volume of LAW glass produced and either increase the required supplemental LAW capacity or the mission duration. In addition, Tc volatility at LAW melter temperatures creates the potential for high Tc concentrations in the secondary waste streams also to be disposed on the Hanford Site.

To reduce the technical uncertainty associated with the long-term environmental impact of Tc, an integrated, systems-based approach will address the ${ }^{99} \mathrm{Tc}$ management issues by evaluating and developing science and engineering options to treat, immobilize, and dispose of the ${ }^{99} \mathrm{Tc}$ contained in tank wastes. This program will address three main areas: 1) Tc inventory, distribution, and speciation, 2) Tc removal, and 3) Tc disposition.

Tc Inventory, Distribution, and Speciation: Several significant uncertainties remain in understanding and modeling the fate and speciation of ${ }^{99} \mathrm{Tc}$ in tanks, glass, and low-temperature waste forms. A significant fraction ( $2 \%$ to $25 \%$ ) of the ${ }^{99} \mathrm{Tc}$ in the water-soluble portion of the tank waste may be present as non-pertechnetate species that have not been identified and, based on experimentation to date, cannot 
be effectively separated from the wastes. It remains uncertain whether alkaline tank conditions even support the formation of proposed low-valent ${ }^{99} \mathrm{Tc}$ species, i.e., Tc(I) carbonyl compounds. The presence of these non-pertechnetate species affects both the ability to separate ${ }^{99} \mathrm{Tc}$ from LAW and the performance of any alternative low-temperature waste forms.

Technetium Removal: A second uncertainty is associated with the effective removal of ${ }^{99} \mathrm{Tc}$ from various process streams. While there has been significant work on the removal of the pertechnetate anion from solution, there has been limited work in the area of removing the non-pertechnetate species and the redox chemistry necessary to convert these species to pertechnetate or some other form that can be removed. In addition, only preliminary tests have been started recently to explore separation of ${ }^{99} \mathrm{Tc}$ from the off-gas scrub solutions.

Technetium Disposition: A third uncertainty is associated with the ${ }^{99} \mathrm{Tc}$ incorporation into waste forms. For example, the ${ }^{99} \mathrm{Tc}$ retention in glass measured experimentally over a broad range of waste compositions varied between about $18 \%$ and $63 \%$ in a single pass without recycle (Abramowitz et al. 2012). Some additives, such as $\mathrm{Fe}(\mathrm{II})$, oxalate, $\mathrm{ZrO}_{2}$, or sugar, showed great promise for enhancing further ${ }^{99} \mathrm{Tc}$ retention by altering the redox chemistry of the melt process, as does a reduced amount of sulfur in the melter feed (Kim et al. 2005, Jin et al. 2014). In certain situations, incorporating ${ }^{99} \mathrm{Tc}$ into low-temperature waste forms may be more appropriate; however, the ${ }^{99} \mathrm{Tc}$ retention mechanisms need to be understood, and the rate of ${ }^{99} \mathrm{Tc}$ release from these low-temperature waste forms needs to be demonstrated to be sufficiently below the required value for onsite disposal.

The Tc management program represents an integrated effort that includes scope funded directly by the Office of River Protection (ORP), DOE subcontractors, and the DOE Office of Environmental Management Headquarters. This program includes work in the three technical areas described above. Currently, ORP has funded work in the area of Tc disposition associated with incorporation of Tc in HLW glass. Washington River Protection Solutions has funded work in the area of Tc disposition associated with the development of SuperLig $639^{\circledR}$ for Tc removal and in the area of Tc inventory associated with developing new test methods for actual waste samples and understanding the stability of select non-pertechnetate species.

This Tc waste-forms literature review is part of the Tc disposition area of work. The objective of the work is to identify and evaluate waste forms specifically for immobilizing Tc separated from Hanford tank wastes. There are a number of waste forms that can be and are being used for immobilizing wastes with a number of chemical and radiochemical contaminants. This report briefly mentions these waste forms in Section 4. The focus of the literature review is on waste forms specifically for Tc. To help differentiate, the fluidized bed steam reforming (FBSR) waste form captures Tc in a sodalite silicate phase. FBSR would be considered a multi-contaminant waste form and is mentioned in Section 4. For this literature review, sodalite would be considered a waste form specific to Tc and is discussed in Section 5 as a method to immobilize Tc specifically. Other activities within the Tc management program are focused on evaluating methods to improve Tc immobilization in low-temperature waste forms such as Cast Stone. That work will be documented in separate reports. 


\subsection{Quality Assurance}

This work was performed in accordance with PNNL's Quality Management System Description and associated Quality Assurance Program Description (QAPD), which are maintained electronically as part of the HDI system. Details of this project's approach to assuring quality are contained in the Environmental Management Support Program Quality Assurance Plan (QA-EMSP-001). Preparation of this report was conducted in accordance with QA-EMSP-1102, Scientific Investigation for Applied Research. All staff members contributing to the work received proper technical and quality assurance training prior to commencing quality-affecting work. 



\subsection{Description of Tc Waste Stream}

Within the WTP flowsheet, soluble Tc is expected to partition to the LAW fraction of the wastes, and Tc associated with undissolved solids plus a small amount of soluble Tc in interstitial liquids is expected to partition to the HLW fraction during the ultrafiltration step in pretreatment. The soluble Tc will be sent to the LAW vitrification facility for incorporation into the LAW glass and to the supplemental LAW immobilization facility, and Tc associated with the undissolved solids will be sent to the HLW vitrification facility for incorporation into the HLW glass.

In the HLW and LAW vitrification facilities, a fraction of the Tc will be incorporated into the HLW and LAW glasses, respectively. Because of the volatility of Tc at the glass melter operating temperatures $\left(\sim 1150^{\circ} \mathrm{C}\right)$, a fraction of the Tc will leave the melters and will be captured in the submerged bed scrubbers (SBS) and wet electrostatic precipitators (WESP) of the primary off-gas treatment systems for each facility. The LAW condensates containing the captured Tc will be returned to the pretreatment facility where they will ultimately be combined with fresh LAW and sent to the LAW vitrification facility. The HLW off-gas condensates will be returned to the pretreatment facility where they will be mixed with HLW feed for filtration. Technetium not captured in the SBS/WESP is expected to be captured on the high-efficiency particulate air (HEPA) filters of the secondary off-gas treatment systems in the HLW and LAW vitrification facilities. Some Tc is also expected to deposit on the process piping within the WTP, which will be back-flushed to the melter during normal operations. Flowsheet modeling suggests that any Tc not captured in the LAW HEPA filters would be captured in the final caustic scrubber of the LAW vitrification secondary off-gas treatment. This caustic scrubber aqueous waste will be combined with other WTP process condensates and sent to the Effluent Treatment Facility (ETF) for treatment and solidification.

Given this WTP flowsheet, there are at least three possible locations for a Tc separations process to be inserted:

- the LAW concentrate from pretreatment to LAW vitrification and/or a supplemental LAW immobilization facility

- the LAW SBS/WESP off-gas condensate recycled back to pretreatment

- the aqueous condensate process stream from pretreatment to the ETF.

The rest of this section describes possible methods for separating Tc from these process streams and the projected composition of the Tc-containing stream from the separations process.

\subsection{Separation Methods}

Several methods have been developed for separating Tc from alkaline radioactive waste solutions. McCabe et al. (2012) recently prepared a data package providing information on five separations approaches as input to a down-selection process for possible implementation of a Tc-removal process. The five Tc-removal technologies identified include

- elutable ion exchange

- non-elutable ion exchange 
- solvent extraction

- electrochemical reduction

- precipitation

These separation methods are intended to remove pertechnetate from the waste solutions. They generally are not effective for separating non-pertechnetate species unless the non-pertechnetate species are first converted to pertechnetate. Conversion methods have been tested, but they are technically immature (McCabe et al. 2012).

\subsubsection{Elutable lon Exchange}

With elutable ion exchange, the waste stream flows through a series of ion exchange columns loaded with the exchange media. When the exchange media becomes loaded with Tc, the waste flow is stopped and steps are taken to strip the Tc from the ion exchange media. The ion exchange media can be used for several load/strip cycles before it must be replaced. The Tc stripped from the ion exchange column is typically in the form of an aqueous solution that can then be further treated and immobilized.

A number of materials have been identified as possible elutable ion exchange media (Duncan et al. 2011). SuperLig ${ }^{\circledR} 639$, ABEC 2000, Dowex ${ }^{\circledR} 1 X 8$, and Reillex ${ }^{\circledR}$ HPQ have been tested with Hanford tank waste. SuperLig 639 is the most technically mature of these technologies (McCabe et al. 2012). Pre-conceptual engineering studies have been prepared for Tc removal using SuperLig 639 from the supplemental LAW feed stream (Russell 2013) and for LAW SBS/WESP condensate (May and Robbins 2013). SuperLig 639 had previously been selected by BNFL for WTP pertechnetate separations before a decision was made to remove that process step. It was rated highest by Duncan et al. (2011) in their review of sorption media for Tc removal from LAW. The one notable concern for the SuperLig 639 separations method is that it is effective only for pertechnetate ion.

\subsubsection{Non-Elutable lon Exchange}

In the non-elutable ion exchange process, the ion exchange media is loaded once by passing the Tc-laden waste stream through the ion exchange bed. When the ion exchange media is loaded, it is removed from the column and is replaced with fresh media. The loaded resin would then be dried and placed in a suitable disposal container or would be further treated before disposal. Among the non-elutable ion exchange resins are Purolite A520E and A530E, and Kurion TAM (a tin apatite sorption media) (Duncan et al. 2011). Reillex HPQ could also be used as a non-elutable ion exchange resin (McCabe et al. 2012).

\subsubsection{Solvent Extraction}

Technetium would be extracted from the waste stream using a crown ether bis-4-4'(5)[tertbutyl)cyclohexane]-18-crown-6 in an organic diluent of a mixture of tributyl phosphate and Isopar L (McCabe et al. 2012). The process was invented at Oak Ridge National Laboratory (Bonnesen et al. 1996). The Tc would be stripped from the extractant into a dilute nitric acid solution. There has been limited testing with Hanford tank waste simulants and actual wastes (McCabe et al. 2012). 


\subsubsection{Electrochemical Reduction}

In an electrochemical reduction process, liquid wastes are processed through electrochemical cells. In reduction mode, the Tc deposits on the cathode, presumably as Tc metal but perhaps also as $\mathrm{TcO}_{2}$ (Lawrence et al. 1997). The Tc would then be redissolved off the cathode into a dilute caustic or acid solution for storage or immobilization (McCabe et al. 2012). Alternatively, the Tc could be retained in the metal form on the electrode for incorporation into a metal alloy waste form. The Tc reduction step could be preceded by an electro-oxidation step to destroy organics in the waste and to convert non-pertechnetate species to the pertechnetate form. The electro-reduction process would also reduce other components in the wastes including nitrate, nitrite, and chromium. The electrochemical reduction process has been demonstrated at the laboratory scale on selected Hanford tank wastes (Lawrence et al. 1997).

\subsubsection{Precipitation}

Removal of Tc from alkaline wastes via precipitation involves the addition of tetraphenylphosphonium ion $\left.\left[\mathrm{C}_{6} \mathrm{H}_{5}\right)_{4} \mathrm{P}\right]^{+}\left(\mathrm{TPP}^{+}\right)(\mathrm{McCabe}$ et al. 2012). The TPP forms an insoluble organic solid with the pertechnetate ion. The process is used at the Enhanced Actinide Removal Plant at the Sellafield, UK fuel reprocessing facility. There the precipitated Tc is removed by filtration and is sludge washed before immobilization in a cement waste form.

\subsection{Nominal Tc Waste Stream Compositions}

Composition information is available from pertechnetate ion exchange separations using SuperLig 639 to remove Tc from Hanford tank waste streams. With SuperLig 639, the $\mathrm{TcO}_{4}{ }^{-}$is stripped from the column using warm water at $50-70^{\circ} \mathrm{C}$. The eluate solution is expected to be slightly caustic due to dilute $\mathrm{NaOH}$ solution used to wash residual feed from the column before the Tc is eluted (King and Calloway 2000). Table 3.1 shows projected compositions of the eluate (Tc enriched) from the SuperLig 639 after the Tc separations process. Concentrations are normalized to moles per mole of sodium ( $\mathrm{Na}$ ). The AZ-102 and AW-101 compositions are based on actual waste samples from these tanks and are based on chemical and radiochemical analyses after filtration, cesium (Cs) removal, and Tc removal (King and Calloway 2000, Hassan et al. 2004). The AZ-102 results are for an eluate after evaporation to concentrate the solution. The AW-101 results are based on the average of four or five separations cycles depending on the analyses conducted on the samples collected. The Hanford Tank Waste Operations Simulator (HTWOS) projections are based on flowsheet model runs for a pre-conceptual engineering study for supplemental immobilization (Russell 2013). In the pre-conceptual engineering study, the Tc separations would be conducted on pretreated LAW in a facility between the pretreatment facility and the supplemental LAW immobilization facility. The Tc eluate would be concentrated and stored until processed in the HLW melters. The HTWOS information in Table 3.1 is for this concentrated stream.

Burgeson et al. (2005) used SuperLig 639 to separate Tc from waste supernates from 241-AP-101; 241-AN-102 blended with C-104 solid filtrate, leach, and wash solutions; 241-AP-104; and 241-AZ-101. Following column loading, the residual feed was washed from the column with $0.10 \mathrm{M} \mathrm{NaOH}$. The Tc was then eluted from the column with deionized water at $65^{\circ} \mathrm{C}$. Table 3.2 shows chemical analyses of the Tc eluate for each tank waste. 
Table 3.1. Concentrations of Tc Eluate Streams After Technetium Separations

\begin{tabular}{cccc}
\hline Species & AZ-102 $^{(\mathbf{a})}$ & AW-101 $^{(\mathbf{b})}$ & HTWOS $^{(\mathbf{c})}$ \\
\hline $\mathrm{mole} / \mathrm{mole} \mathrm{Na}$ & mole / mole Na & mole / mole Na \\
\hline $\mathrm{B}$ & 0.015 & 0.067 & 0.102 \\
$\mathrm{Cr}$ & 0.007 & 0.046 & - \\
$\mathrm{K}$ & 0.003 & - & 0.007 \\
$\mathrm{Na}$ & 0.020 & 0.147 & 0.007 \\
$\mathrm{Si}$ & 1.000 & 1.000 & 1.000 \\
$\mathrm{Tc}$ & 0.001 & 0.028 & 0.004 \\
$\mathrm{CO}$ & $0.0073^{(\mathrm{e})}$ & 0.001 \\
$\mathrm{Cl}$ & 0.0037 & $\mathrm{NR}$ & 0.047 \\
$\mathrm{~F}$ & $\mathrm{NR}$ & 0.014 & 0.009 \\
$\mathrm{NO}_{3}$ & $\mathrm{NR}$ & - & 0.025 \\
$\mathrm{NO}_{2}$ & $\mathrm{NR}$ & 0.213 & 0.324 \\
$\mathrm{C}_{2} \mathrm{O}_{4}$ & $\mathrm{NR}$ & 0.133 & 0.127 \\
$\mathrm{PO}_{4}$ & $\mathrm{NR}$ & - & 0.002 \\
$\mathrm{SO}_{4}$ & $\mathrm{NR}$ & 0.044 from P & 0.005 \\
\hline
\end{tabular}

(a) Adapted from King and Calloway (2000).

(b) Adapted from Hassan et al. (2004). Tc concentration based on $\mu \mathrm{Ci} / \mathrm{mL}$.

(c) Adapted from Russell (2013).

(d) $\mathrm{NR}=$ not reported, dash $(-)=$ reported as less than value.

(e) There is some discrepancy between the tables and text in Hassan et al. (2004) regarding the Tc concentration in the eluates. The text gives concentrations in $\mu \mathrm{Ci} / \mathrm{mL}$ but the table concentrations are given in $\mathrm{mCi} / \mathrm{mL}$. The values in this table are based on $\mu \mathrm{Ci} / \mathrm{mL}$ concentration values. 
Table 3.2. Tc Eluate Concentrations from Hanford Tank Waste Samples

\begin{tabular}{ccccc}
\hline Species $^{(\text {a) }}$ & AP-101 & $\begin{array}{c}\text { AN-102/C-104 } \\
\text { Blend }\end{array}$ & AP-104 & AZ-101 \\
\hline & mole / mole Na & mole / mole Na & mole / mole Na & mole / mole Na \\
\hline $\mathrm{Na}$ & 1.000 & 1.000 & 1.000 & 1.000 \\
$\mathrm{~K}$ & 0.000 & 0.000 & 0.000 & 0.116 \\
$\mathrm{Al}$ & 0.034 & 0.000 & 0.000 & 0.000 \\
$\mathrm{Cr}$ & 0.175 & 0.000 & 0.000 & 0.000 \\
$\mathrm{Tc}$ & 0.018 & 0.009 & 0.027 & 0.251 \\
$\mathrm{Cl}$ & 0.004 & 0.007 & 0.012 & 0.002 \\
$\mathrm{~F}$ & 0.000 & 0.048 & 0.000 & 0.011 \\
$\mathrm{CO}_{3}$ & 0.175 & 0.754 & 0.333 & 0.211 \\
$\mathrm{OH}$ & 0.299 & 0.000 & 0.417 & 0.316 \\
$\mathrm{NO}_{3}$ & 0.107 & 0.172 & 0.083 & 0.073 \\
$\mathrm{NO}_{2}$ & 0.044 & 0.090 & 0.054 & 0.101 \\
$\mathrm{C}_{2} \mathrm{O}_{4}$ & 0.001 & 0.002 & 0.001 & 0.001 \\
$\mathrm{PO}_{4}$ & 0.000 & 0.000 & 0.001 & 0.002 \\
$\mathrm{SO}_{4}$ & 0.003 & 0.008 & 0.006 & 0.014 \\
\hline
\end{tabular}

(a) Adapted from Burgeson et al. (2005). 



\subsection{Multi-Contaminant Waste Forms}

A number of waste forms have been developed over the years for immobilization of a suite of radionuclides typically found in wastes from reactor fuel reprocessing and fabrication (IAEA 1977; Lutze and Ewing 1988; Ojovan and Lee 2005; Pierce et al. 2010; NRC 2011; Ojovan 2011 and references therein; Lee et al. 2013). Borosilicate glass is used almost universally for immobilization of HLW and also will be used at the Hanford Site for the immobilization of LAW. Cementitious grouts are used extensively for solidification of aqueous low-level wastes. Other waste forms have been developed as alternatives to glass and grout for waste immobilization. These include geopolymers, phosphate-bonded ceramics, FBSR-generated aluminosilicates, and Synroc.

These waste forms are all designed to immobilize the range of radionuclides and chemicals present in HLW and LAW. They are mentioned here in this literature survey to acknowledge the work that has been done to capture Tc in these waste forms but they are not discussed in detail. Some of the multi-contaminant waste forms are designed to capture Tc in a specific phase. Those phases are mentioned here, and Section 5 provides more detail regarding those specific phases as unique waste forms for Tc.

\subsection{Glass}

Radioactive waste glasses are produced through high-temperature processes in which the waste and glass formers (glass-forming chemicals or a premelted glass frit) are mixed and placed in a glass melter operating at $\sim 950^{\circ}$ to $1250^{\circ} \mathrm{C}$. The resulting molten glass is poured into a steel container for storage and disposal. Borosilicate glass is commonly used for radioactive waste solidification, but aluminum phosphate glass is also used in Russia.

Retention of Tc at the glass melting temperature is challenging because of the volatility of Tc at the high melting temperatures. Darab and Smith (1996) conducted an extensive review of the literature regarding volatility of $\mathrm{Tc}$ and $\mathrm{Re}$. Technetium oxides $\mathrm{Tc}_{2} \mathrm{O}_{7}$ boils at $311^{\circ} \mathrm{C}$ and $\mathrm{TcO}_{2}$ sublimes at $900^{\circ}$ to $1000^{\circ} \mathrm{C}$ (Darab and Smith 1996). Alkali salts $\left(\mathrm{KTcO}_{4}, \mathrm{NaTcO}_{4}\right)$ are expected to be less volatile because of their higher melting points $\left(532^{\circ} \mathrm{C}\right.$ and $378^{\circ} \mathrm{C}$, respectively) relative to the boiling point of $\mathrm{Tc}_{2} \mathrm{O}_{7}$. May et al. (2010) include an overview of Tc behavior in LAW vitrification. Tc retention in borosilicate glass melts has been observed from 12 to $77 \%$, with a couple of examples at $99 \%$. These are based on a single pass of the Tc through the melter. Because of the low retention in a single pass, the waste vitrification plants are designed to recycle the off-gas condensates back to the melter feed. This has been effective in increasing the Tc retention, but at the expense of additional glass production and longer mission durations. May et al. (2010) describe work to further improve the retention of Tc during the melting process.

\subsubsection{Borosilicate Glass}

Borosilicate glass is used almost universally for the immobilization of HLW from spent fuel reprocessing, the exception being aluminophosphate glass produced at Mayak in Russia. Typically, the radioactive wastes are mixed with glass-forming chemicals or a glass frit and then are fed into a glass-melting furnace operating at temperatures from $\sim 1000$ to $1250^{\circ} \mathrm{C}$. In the United States, the wastes 
are added as aqueous solutions to the glass-forming chemicals or frit. In France and the United Kingdom, the aqueous wastes are calcined before mixing with the glass formers. As the glass-forming chemicals melt, the waste components react to form a borosilicate melt in the melter. The molten glass is poured into steel containers where it solidifies into a borosilicate glass waste form. The glass inside the steel canisters is stored until placed in the disposal facility. The radionuclides are chemically bound in the glass matrix and thus are released into the environment by the very slow corrosion of the glass in the disposal environment.

Extensive work has been conducted over several decades developing formulations for HLW and LAW glasses. Because of the variability in the compositions of waste to be vitrified, there is not a single HLW or LAW glass formulation. Rather, composition/property models have been developed to guide the formulation of glasses in response to the composition of the specific waste stream to be vitrified (HLW: Vienna and Kim 2008, Vienna et al. 2009; LAW: Piepel et al. 2007, Kim and Vienna 2012, Vienna et al. 2013). Table 4.1 shows examples of LAW glass formulations for Hanford LAW (Pierce et al. 2004). The first three formulations are for simulated wastes representing three broad waste composition envelopes for the LAW. The last two columns are for two actual waste glass samples. These glasses have been characterized extensively to support performance assessment analyses.

Table 4.1. Example LAW Glass Compositions for Hanford Tank Wastes (from Pierce et al. 2004)

\begin{tabular}{|c|c|c|c|c|c|}
\hline Oxide $^{(a)}$ & LAWA44 & LAWB45 & LAWC22 & LAWAN102 & LAWAP101 \\
\hline $\mathrm{Al}_{2} \mathrm{O}_{3}$ & 6.20 & 6.13 & 6.08 & 6.19 & 5.66 \\
\hline $\mathrm{B}_{2} \mathrm{O}_{3}$ & 8.90 & 12.34 & 10.06 & 10.05 & 9.85 \\
\hline $\mathrm{CaO}$ & 1.99 & 6.63 & 5.12 & 6.24 & 2.00 \\
\hline $\mathrm{Cl}$ & 0.65 & 0.01 & 0.09 & 0.03 & 0.17 \\
\hline $\mathrm{Cr}_{2} \mathrm{O}_{3}$ & 0.02 & 0.07 & 0.02 & 0.08 & 0.03 \\
\hline $\mathrm{F}$ & 0.01 & 0.08 & 0.16 & - & 0.27 \\
\hline $\mathrm{Fe}_{2} \mathrm{O}_{3}$ & 6.98 & 5.26 & 5.43 & 6.94 & 5.56 \\
\hline $\mathrm{K}_{2} \mathrm{O}$ & 0.50 & 0.26 & 0.10 & 0.19 & 3.82 \\
\hline $\mathrm{Li}_{2} \mathrm{O}$ & - & 4.62 & 2.51 & 2.76 & - \\
\hline $\mathrm{MgO}$ & 1.99 & 2.97 & 1.51 & 1.41 & 1.49 \\
\hline $\mathrm{Na}_{2} \mathrm{O}$ & 20.00 & 6.50 & 14.4 & 11.23 & 18.46 \\
\hline $\mathrm{NiO}$ & - & - & 0.03 & 0.08 & 0.01 \\
\hline $\mathrm{P}_{2} \mathrm{O}_{5}$ & 0.03 & 0.03 & 0.17 & 0.17 & 0.09 \\
\hline $\mathrm{SO}_{3}$ & 0.10 & 0.84 & 0.34 & 0.31 & 0.31 \\
\hline $\mathrm{SiO}_{2}$ & 44.55 & 47.86 & 46.67 & 47.41 & 44.27 \\
\hline $\mathrm{TcO}_{2}$ & - & - & - & 0.0001 & 0.001 \\
\hline $\mathrm{TiO}_{2}$ & 1.99 & - & 1.14 & 1.24 & 2.01 \\
\hline $\mathrm{ZnO}$ & 2.96 & 3.15 & 3.07 & 2.99 & 2.97 \\
\hline $\mathrm{ZrO}_{2}$ & 2.99 & 3.15 & 3.03 & 2.54 & 3.01 \\
\hline
\end{tabular}

Soderquist et al. (2014) determined the solubility and form of Tc in LAW glasses. They determined that the solubility of Tc is approximately 2000 parts per million (ppm) for a LAW glass melted at $1000^{\circ} \mathrm{C}$. The solubility increased to approximately $2800 \mathrm{ppm}$ under slightly reducing conditions. This is several orders of magnitude greater than the expected Tc concentrations in LAW glasses. Though the Tc was introduced in the waste simulant as the pertechnetate ( $\mathrm{Tc}(\mathrm{VII})$ ), its form in the glass was primarily as the Tc(IV) form, mostly as a well-dispersed, isolated six-coordination ion. The reduction of Tc is most likely due to $\mathrm{Fe}(\mathrm{II})$ species in the glass. 
There have been extensive studies of glass corrosion spanning more than three decades (Barkatt et al. 1986; Hench et al. 1986; Bunker et al. 1988; Casey and Bunker 1990; Werme et al. 1990; Bourcier 1991, 1994; Vernaz and Dussossoy 1992; Cunnane et al. 1994a,b; McGrail et al. 1997; Strachan and Croak 2000; Vernaz et al. 2001; Icenhower et al. 2004; Van Iseghem et al. 2004). The glass dissolution process can be divided into five stages (Pierce et al. 2011) including

1. Initial diffusion or interdiffusion. Network modifying cations in the glass and protons in solutions are exchanged.

2. Initial or forward rate. Hydration and dissolution of the glass network in dilute solutions is governed by temperature, $\mathrm{pH}$, and reactive surface area.

3. Decreasing rate. As the solution becomes more concentrated, a hydrated surface layer forms on the glass surface as relatively insoluble glass components (Al, Fe, and $\mathrm{Si}$ ) accumulate in the solution.

4. Residual rate. The solution becomes saturated and secondary minerals begin to form.

5. Alteration renewal. Depending on the type of alteration phase, the glass-water reaction can increase from the residual rate to a rate consistent with the initial or forward rate of Stage 2.

A rate equation describing the glass dissolution process has been developed based on the Transition State Theory of chemical kinetics (Pierce et al. 2004). The overall reaction rate is governed by the slowest elementary reaction. The rate equation describes the rate of reaction in terms of the solution $\mathrm{pH}$, temperature, saturation state of the system, and the chemical activities of species that enhance or inhibit the reactions. Test methods including the Single-Pass Flow-Through (SPFT) test (McGrail et al. 2000), Pressurized Unsaturated Flow (PUF) test (McGrail et al. 2001), and Product Consistency Test (PCT, ASTM 2008A) are needed to determine the parameters for the kinetic rate equation (Pierce et al. 2004).

\subsubsection{Phosphate Glasses}

Aluminophosphate glasses are used in Russia to immobilize their HLW, and iron phosphate glasses have been evaluated as an alternative waste form for Hanford LAW (Kim and Day 2003; Kim et al. 2003a; Kim et al. 2003b; Kim et al. 2004; Day et al. 2012; Sevigny et al. 2012). Iron phosphate glasses are of interest for vitrification of radioactive wastes because of their very good chemical durability and their compatibility with wastes that contain transition metals, phosphate, sulfate, and halides that may reduce the waste loading in borosilicate glasses. Table 4.2 shows the batch compositions of several iron phosphate glasses.

Xu et al. (2013) looked specifically at the solubility of Tc and Re within an iron phosphate glass. They determined that Re has a solubility limit of approximately 1.1 mass percent when held at the $1000^{\circ} \mathrm{C}$ melt temperature for 10 minutes. They also observed that more Re volatilized with increased time at the melt temperature and with increased melting temperature. Thus, retention of Tc is expected to be an issue with iron phosphate glasses as it is with borosilicate glasses due to the high melting temperatures. 
Table 4.2. Nominal Compositions of LAW Iron Phosphate Glasses

\begin{tabular}{|c|c|c|c|c|c|c|c|}
\hline Oxide & IP30LAW $^{(a)}$ & IP30LAW-A $^{(\mathbf{a})}$ & IP30LAW-C ${ }^{(\mathbf{a})}$ & IP27LAW $^{(\mathbf{b})}$ & IP32LAW $^{(\mathbf{b})}$ & IP35LAW $^{(\mathbf{b})}$ & $\begin{array}{c}\text { MS26 } \\
\text { AZ102 } \\
\text { F-2 }^{(\mathbf{c})}\end{array}$ \\
\hline & wt $\%$ & wt $\%$ & wt $\%$ & wt $\%$ & wt $\%$ & wt $\%$ & $\mathrm{wt} \%$ \\
\hline $\mathrm{Al}_{2} \mathrm{O}_{3}$ & 1.3 & 11.3 & 1.3 & 16.2 & 15.4 & 14.9 & 13.21 \\
\hline $\mathrm{B}_{2} \mathrm{O}_{3}$ & - & - & - & - & - & - & 0.03 \\
\hline $\mathrm{Cl}$ & 0.2 & 0.2 & 0.2 & 0.2 & 0.2 & 0.2 & 0.04 \\
\hline $\mathrm{Cr}_{2} \mathrm{O}_{3}$ & 0.1 & 0.1 & 3.1 & 3.4 & 3.2 & 3.0 & 2.7 \\
\hline $\mathrm{Cs}_{2} \mathrm{O}$ & - & - & - & - & - & - & 0.13 \\
\hline $\mathrm{F}$ & 0.5 & 0.5 & 0.5 & 1.1 & 1.1 & 1.1 & 0.16 \\
\hline $\mathrm{Fe}_{2} \mathrm{O}_{3}$ & 20.0 & 10.0 & 17.0 & 7.2 & 6.7 & 6.4 & 7.1 \\
\hline $\mathrm{K}_{2} \mathrm{O}$ & - & - & - & - & - & - & 0.78 \\
\hline $\mathrm{Na}_{2} \mathrm{O}$ & 22.6 & 22.6 & 22.6 & 20.3 & 24.1 & 26.4 & 20.3 \\
\hline $\mathrm{P}_{2} \mathrm{O}_{5}$ & 52.2 & 52.2 & 52.2 & 29.2 & 27.7 & 26.8 & 38.6 \\
\hline $\mathrm{Re}_{2} \mathrm{O}_{3}$ & - & - & - & - & - & - & 0.03 \\
\hline $\mathrm{SiO}_{2}$ & 0.2 & 0.2 & 0.2 & 12.4 & 11.7 & 11.2 & 5.58 \\
\hline $\mathrm{SO}_{3}$ & 2.9 & 2.9 & 2.9 & 2.6 & 3.0 & 3.3 & 4.37 \\
\hline $\mathrm{Bi}_{2} \mathrm{O}_{3}$ & - & - & - & 2.7 & 2.5 & 2.4 & 1.77 \\
\hline $\mathrm{La}_{2} \mathrm{O}_{3}$ & - & - & - & 1.2 & 1.1 & 1.1 & 0.71 \\
\hline $\mathrm{ZrO}_{2}$ & - & - & - & 2.7 & 2.5 & 2.4 & 0.71 \\
\hline $\mathrm{ZnO}$ & - & - & - & - & - & - & 3.55 \\
\hline $\mathrm{CaO}$ & - & - & - & 1.0 & 1.0 & 1.0 & 1.06 \\
\hline
\end{tabular}

\subsection{Grouts}

As used at Hanford, the term Cast Stone describes a "grout"-based waste form made predominantly with fly ash and blast furnace slag (BFS) with lesser amounts of Portland cement as the starting dry blend (Serne and Westsik 2011 and references therein). At Savannah River, this waste form is called Saltstone. The blend of grout reagents in Saltstone has been constant (45 wt \% Grade 100 slag cement, $45 \mathrm{wt} \%$ Class F fly ash, and $10 \mathrm{wt} \%$ Type I/II Portland cement) since the Saltstone Disposal Facility began production in the early 1990s. All the current Cast Stone waste form testing uses a dry blend consisting of $47 \mathrm{wt} \%$ BFS (Grade 100), $45 \mathrm{wt} \%$ fly ash (Class F), and $8 \mathrm{wt} \%$ Portland cement (Type I/II). The sources of the three dry blend ingredients used at Hanford and Savannah River differ, which have subtle impacts on the physical and chemical attributes of the subsequent grout waste forms. Other minor ingredients, such as lime (calcium hydroxide), clays, zeolites, and "getter" materials are sometimes added to the grout dry blend mix to improve either physical stability or chemical properties (e.g., to improve retention of contaminants) (Serne and Westsik 2011 and references therein). For some formulations, either the fly ash or BFS is omitted from the dry blend or replaced by another material (Serne and Westsik 2011 and references therein).

Key properties desired and accomplished by using grouts are 1) creation of a solid waste form that has adequate physical strength to withstand handling and transportation to a final disposal facility, 
2) contaminants of concern present in the liquid waste are retained by a combination of physical and chemical processes in the grout waste form, and 3) resistance to dissolution/disintegration by recharge water or atmospheric gases percolating through the disposal facility. The basic process that occurs when the grout dry ingredients are mixed with liquid wastes is called hydration; this refers to chemical reactions between the compounds in the dry blend with water from the liquid waste that form new minerals and solids that bind together to form a cohesive, rather impermeable, but porous mass that both physically and chemically entraps waste species. By tailoring the dry blend proportions, the hardened cohesive solid contains mostly very small pores (nano- and micro-meter-sized) that are tortuously connected, which results in a solid with very low permeability or hydraulic conductivity. Thus, the flow of water through the grout solid is very slow, such that diffusion becomes the main mechanism for dissolved species to migrate out of the solid.

The key attributes of the Portland cement and BFS that make grouts a good waste form are

- the high-pH environment of the grout matrix, which lowers the solubility of most metallic constituents,

- good chemical and physical stabilization properties for most contaminants of concern present in the liquid waste,

- the relatively low hydraulic conductivity (permeability) of the hardened paste to both water and gas transport,

- relatively long-term physical and chemical durability under near-surface environmental conditions. Although some contaminants can be incorporated into the structure of the hydrated calcium silicate phases, the precipitation of low-solubility metal hydroxides in the high-pH internal pore-water environment is the primary stabilization mechanism.

- Making grout is a low-temperature process that does not require off-gas capture of volatile species such as Tc.

When one considers the extensive literature on the use of cementitious material in the construction industry, the available database is very large, and the understanding of how to tailor grout formulations to yield desired physical and, to some extent, chemical properties is robust. Successful production of grout waste forms has been demonstrated from laboratory-scale monoliths with volumes of $\mathrm{cm}^{3}$ to $\mathrm{m}^{3}$ sized blocks, to 210-liter-sized drums, and all the way to the large pours of Saltstone into vaults at the Savannah River Site (SRS). To date, over 9 million gallons of low-level liquid waste have been solidified as Saltstone and disposed in concrete vaults at the SRS. Additional favorable attributes include the following:

- Producing a grout waste form does not require complicated processes or unusually specialized equipment (see Appendix F in Serne and Westsik 2011 for descriptions of SRS Saltstone equipment). Waste solidification in grout is a mature process. The costs of the starting ingredients and equipment necessary to generate these grout waste forms are low compared to some other low-temperature waste forms. Based on internet searches, average prices are $\$ 100$ per ton for Portland cement, $\$ 15$ per ton for fly ash, and $\sim \$ 90$ to $\$ 100$ per ton for granulated BFS. 
- Short-term (63 days) leach rates for key contaminants, such as ${ }^{99} \mathrm{Tc}$ and hazardous metals regulated by the Resource Conservation and Recovery Act (RCRA 1976), are quite low compared to the preliminary target release criteria for final waste form disposal (see Serne and Westsik 2011 for detailed discussion). Further, there is a trend of decreasing leaching as function of time for all Cast Stone and Saltstone monolith tests using intermittent deionized water exchanges, suggesting near-surface wash off is biasing the early leach performance.

- The compressive strengths of almost all Cast Stone and Saltstone monoliths prepared with highly caustic and saline liquid wastes exceed the IDF provisional compressive strength criterion of $500 \mathrm{psi}^{1}$, generally by at least a factor of two.

The Cast Stone and Saltstone dry blends, with 45 to $47 \%$ BFS, are an effective reductant for ${ }^{99} \mathrm{TcO}_{4}{ }^{-}$ and other redox-sensitive RCRA metals such as $\mathrm{Cr}(\mathrm{VI})$, $\mathrm{Se}(\mathrm{VI})$, and $\mathrm{As}(\mathrm{V})$. BFS was first studied as a reductant at Savannah River National Laboratory (SRNL). Most telling are leach test results discussed in Langton (1988) that show significant differences in effective diffusion coefficients for $\mathrm{Cr}(\mathrm{VI})$ and ${ }^{99} \mathrm{Tc}$ in variants of the Saltstone dry mix with and without BFS. When BFS is part of the dry mix at $25 \%$ of the final hardened Saltstone, the effective diffusion coefficients for $\mathrm{Cr}(\mathrm{VI})$ and ${ }^{99} \mathrm{Tc}$ are four and almost three orders of magnitude lower, respectively, than when BFS is not present in the waste form (see Table 7.9 in Serne and Westsik 2011 for details). The obvious implication is that the BFS has reduced the $\operatorname{Cr}(\mathrm{VI})$ and $\mathrm{Tc}$ (VII) species to their much less soluble $\mathrm{Cr}$ (III) and $\mathrm{Tc}(\mathrm{IV})$ species, thus significantly lowering their apparent leach rates.

All the literature reviewed that explicitly addresses the mechanism for keeping ${ }^{99} \mathrm{Tc}$ sequestered in Cast Stone and Saltstone suggests that BFS reduces mobile pertechnetate $\mathrm{Tc}$ (VII) species in the liquid wastes to a relatively insoluble species, Tc(IV), which co-precipitates and/or adsorbs in the grout interior. $\mathrm{Tc}(\mathrm{IV})$ is much less soluble in grout pore fluids and also exhibits much greater adsorption properties at the $\mathrm{pH}$ conditions of grout waste forms. Thus, the reduced Tc(IV) species is likely controlled by both solubility and adsorption chemical mechanisms. The key component in the BFS that appears to promote the reduction process is sulfide $\left(\mathrm{S}^{2-}\right)$ present in the glassy phases of the BFS. Harbour and Aloy (2007), Lukens et al. (2005), and Allen et al. (1997) determined the speciation of ${ }^{99} \mathrm{Tc}$ in Saltstone waste forms made with simulant waste containing only $\mathrm{Tc}(\mathrm{VII})$ using the $\mathrm{x}$-ray absorption near-edge structure (XANES) technique. Lukens et al. (2005) found, using XANES, that reduced Tc(IV) species were present in the hardened waste form and predominated over residual Tc(VII) species in small $(1.0 \times 0.4 \times$ $4.5 \mathrm{~cm}$ rectangular cuvette) specimens for up to 30 months. The Tc(IV) species ranged from 85 to $90 \%$ of the total Tc in the small specimens over five measurements during the 30 months. When the small grout samples were removed from the poly(methyl methacrylate) cuvettes and exposed to air, the percentage of $\mathrm{Tc}(\mathrm{IV})$ in the small specimens decreased to 45 to $60 \%$ after four months' exposure to air. This suggests that reoxidation of Tc in reducing grouts, such as Cast Stone and Saltstone, needs to be considered.

\footnotetext{
${ }^{1}$ IDF waste acceptance criteria have not been established for all wastes to be disposed of in the facility. There have been several draft waste acceptance criteria proposals, some limited to the ILAW glass waste form and bulk vitrification waste form. Others have included criteria applicable to other waste forms as well. Appendix B in Serne and Westsik (2011) lists initial draft waste acceptance criteria for a secondary waste form based on the February 2005 draft IDF waste acceptance criteria (Burbank 2005). Included are criteria with respect to free liquids, compliance with land disposal restrictions, compressive strength, and leachability of selected species from the waste form.
} 
As described above, Lukens et al. (2005), and more recently others such as Um et al. (2011b), present data showing relatively rapid reoxidation of Tc within reducing grouts upon their exposure to air or, to a lesser extent, oxygenated waters. The key issue for long-term performance is how long the reducing environment promoted by the presence of the BFS can be maintained within the buried grout waste forms. Some simplistic calculations have been performed based on the conceptual model that oxygen diffusion into these reducing grouts (when buried in vadose zone subsurface environments) will control the Tc(IV) reoxidation. The key parameters used in this "shrinking core" conceptual model are the diffusion rate of oxygen into the grout, the overall reducing capacity of the grout, and the size (ratio of oxygen-exposed surface area to volume) of the grout. Smith and Walton (1993), Kaplan (2003), Kaplan et al. (2005), and Roberts and Kaplan (2009) present details. The three Kaplan reports suggest that for the very large Saltstone disposal vaults, the amount of Saltstone that is reoxidized is insignificant over a 10,000-year time period.

For smaller-sized reducing grout monoliths (because of their larger ratio of surface area to volume), oxygen diffusion into the waste form and reoxidation of Tc(IV) may be an issue that needs to be considered. Recently Langton and Almond (2013) performed experiments wherein the tops of reducing grout cylinders were exposed to moist air and then the grouts were sectioned into thin slices from top to bottom. The thin sections were leached in water for a short period to determine the depth at which reduced $\mathrm{Cr}$ and $\mathrm{Tc}$ were reoxidized - only oxidized $\mathrm{Cr}$ and $\mathrm{Tc}$ are expected to water leach. One of their key conclusions from the preliminary tests was that the standard Ce(IV) method used to measure the reduction capacity of reducing grouts does not correlate with the depths at which $\mathrm{Cr}$ and $\mathrm{Tc}$ appear to be reoxidized. Langton and Almond (2013) also recommend that exposure tests need to be performed for longer time periods (68 days was used in their tests) on reduced grout specimens that have first been cured for varying time frames (because the BFS slag reduction reactions appear to continue long after the standard 28-day specimen curing times).

The issue of reoxidation of Tc(IV) in reducing grouts remains open and will require additional studies. Regarding the general issue of oxidation state inside the final waste form, short-term measurements of the reduction capacity are problematic in that the measurements probably reflect a nonequilibrium situation, in which good reducing agents such as BFS and stannous salts (used in other low-temperature waste form recipes) coexist with oxidizing agents such as nitrate in the liquid wastes. Reductive capacity measurements on the freshly cured waste forms probably reflect the outcome of competing rapid reaction rates, but ultimately the relative masses of the different reducing and oxidizing constituents and the availability of oxygen in the final shallow land burial environment will prevail in the long term. An appropriate Tc-specific reduction capacity method needs to be found or perhaps the approach of Langton and Almond (2013) to directly measure the depth of oxygen penetration within reducing grout specimens should be adopted. Whichever method is adopted, predictive models will need to be used to assess how long it will take for the waste forms to reach redox equilibrium and at what oxidation-reduction potential $(\mathrm{Eh})$ value the equilibrium is reached.

To date there have been no studies to determine how much ${ }^{99} \mathrm{Tc}$ can be loaded into grout waste forms, likely because the ${ }^{99} \mathrm{Tc}$ concentration in relevant waste streams is very low (a few hundred ppm at most). Therefore, grout should not be impacted by variations in such a minor component.

Using an actual Hanford LAW salt brine, Lockrem (2005) made Cast Stone waste forms that contained between 10.2 and $24.2 \%$ dry waste salts. The leach rates (as quantified by effective diffusion coefficients) for ${ }^{99} \mathrm{Tc}$ in these Cast Stone formulations ranged from $4.0 \times 10^{-11}$ to $3.2 \times 10^{-10} \mathrm{~cm}^{2} / \mathrm{s}$. The 
lowest release rate $\left(4.0 \times 10^{-11} \mathrm{~cm}^{2} / \mathrm{s}\right)$ was for the formulation with the lowest salt loading, and the highest release rate $\left(3.2 \times 10^{-10} \mathrm{~cm}^{2} / \mathrm{s}\right)$ was for the highest salt loading. In more recent studies, Westsik et al. (2013) performed U. S. Environmental Protection Agency (EPA) 1315 leach tests on 24 Cast Stone formulations consisting of four LAW simulants (spiked with $\left.{ }^{99} \mathrm{TcO}_{4}{ }^{-}\right)$used at two concentrations $(5 \mathrm{M} \mathrm{Na}$ and $7.8 \mathrm{M} \mathrm{Na}$ ) and at two water-to-dry-blend mix ratios $(0.4$ and 0.6$)$. The overall ${ }^{99} \mathrm{Tc}$ mean and median effective diffusion coefficients for these 24 formulations were $7.67 \times 10^{-11}$ and $5.30 \times 10^{-11} \mathrm{~cm}^{2} / \mathrm{s}$, respectively.

Regardless, the salient details from all these short-term (months to a few years) solid-phase characterization studies and companion monolith leach tests are that

- the BFS does reduce the majority of the pertechnetate anion from the +7 valence state to the +4 valence state. It may be reduced first to polyatomic technetium-sulfur species in which the Tc is tetravalent, such as $\mathrm{Tc}_{2} \mathrm{~S}_{7}$, with a structure $\mathrm{Tc}_{2} \mathrm{~S}\left(\mathrm{~S}_{2}\right)_{3}$ in which six of the sulfur atoms are present as disulfides (-S-S-, with a net -2 charge for the dimer) rather than sulfides $\left(\mathrm{S}^{2-}\right)$. Recent work suggests that the Tc(IV)-polysulfide species rapidly change to solid Tc(IV) oxides such as $\mathrm{TcO}_{2} \cdot \mathrm{H}_{2} \mathrm{O}$; and

- the effective diffusion coefficient of ${ }^{99} \mathrm{Tc}$ measured by standard monolith leach tests is actually a response to a more complicated reactive transport process where both oxygen-containing species move into the sample, Tc-containing phases react, and pertechnetate ions move out of the sample. More discussion of the leach test results for ${ }^{99} \mathrm{Tc}$ from the Saltstone/Cast Stone waste forms can be found in Section 6.1 of Serne and Westsik (2011).

\subsection{Geopolymer}

DuraLith is an alkali-activated geopolymer waste form developed by the Vitreous State Laboratory at The Catholic University of America for encapsulating liquid radioactive waste. A DuraLith waste form developed for treating Hanford secondary waste liquids is prepared by alkali-activation of a mixture of ground BFS and metakaolin, with sand used as a filler material (Mattigod and Westsik 2011a). The process is conducted at ambient temperature. Based on optimization tests, solid waste loadings of $\sim 7.5 \mathrm{wt} \%$ and $\sim 14.7 \mathrm{wt} \%$ (based on the dissolved solids in the waste) have been achieved using the Hanford secondary waste S1 and S4 simulants, respectively (Mattigod and Westsik 2011a). The Na concentration in the waste was equivalent to $\sim 6 \mathrm{M}$ in both cases. Some of the critical parameters for the DuraLith process include hydrogen generation and heat evolution during preparation of activator solution using the waste simulant, heat evolution during and after mixing the activator solution with the dry ingredients, and a working window of $\sim 20$ minutes to complete the pouring of the DuraLith mixture into waste-form containers. Results of the most recent testing indicated that the working window can be extended to $\sim 30$ minutes if $75 \mathrm{wt} \%$ of the binder components, namely BFS and metakaolin, are replaced by Class F fly ash (Mattigod and Westsik 2011a).

The results of the non-regulatory leach tests, EPA Draft Methods 1313 (EPA 2012a) and 1316 (2012b) conducted on Waste Simulant S1-optimized DuraLith specimens indicated that the concentrations of RCRA metals $(\mathrm{Ag}, \mathrm{Cd}, \mathrm{Cr}, \mathrm{Hg}$, and $\mathrm{Pb})$ in the leachates were well below the Universal Treatment Standard limits in 40 CFR 268.48. The data from the EPA Draft Method 1315 (EPA 2009) leach test showed that effective diffusivity for ${ }^{99} \mathrm{Tc}$ ranged from $6 \times 10^{-9}$ to $4 \times 10^{-12} \mathrm{~cm}^{2} / \mathrm{s}$. 
Results of the Toxicity Characteristic Leaching Procedure (TCLP) (EPA Method 1311, EPA 1992) conducted on Waste Simulant S1-optimized DuraLith specimens indicated that the concentrations of RCRA metals (Ag, As, Cd, Cr, Hg, and Pb) in the leachates were well below the Universal Treatment Standard limits in 40 CFR 268.48. The results of the compressive strength testing of Waste Simulant S1-optimized DuraLith specimens indicated that the monoliths were physically robust, with compressive strengths ranging from $115.5 \mathrm{MPa}(16,757 \mathrm{psi})$ to $156.2 \mathrm{MPa}(22,667 \mathrm{psi})$.

\subsection{Phosphate-Bonded Ceramics}

Ceramicrete is a relatively new engineering material developed at Argonne National Laboratory to treat radioactive and hazardous waste streams (e.g., Wagh 2004; Wagh et al. 1999, Wagh and Jeong 2003; Singh et al. 2000, Singh et al. 2011, Cantrell and Westsik 2011). This cement-like waste form can be used to treat solids, liquids, and sludges by chemical immobilization, microencapsulation, and/or macroencapsulation. The Ceramicrete technology is based on chemical reactions between phosphate anions and metal cations to form a strong, dense, durable, and low-porosity matrix that immobilizes hazardous and radioactive contaminants as insoluble phosphates and microencapsulates insoluble radioactive components. Ceramicrete is a type of chemically bonded phosphate ceramic. The Ceramicrete binder is formed through an acid-base reaction between calcined magnesium oxide $(\mathrm{MgO}, \mathrm{a}$ base) and potassium hydrogen phosphate $\left(\mathrm{KH}_{2} \mathrm{PO}_{4}\right.$, an acid) in aqueous solution. The reaction product sets at room temperature to form a highly crystalline material. During the reaction, the hazardous and radioactive contaminants also react with $\mathrm{KH}_{2} \mathrm{PO}_{4}$ to form highly insoluble phosphates.

Ingredients for Ceramicrete waste forms include magnesium oxide, monopotassium phosphate, and water. Filler materials such as calcium silicate or wollastonite, fly ash, and/or BFS are added to reduce costs and may actually improve the performance of the Ceramicrete. To reduce the mobility of some contaminants, getter materials are added. Silver zeolite is used to retain iodine (Russell et al. 2006). Tin chloride $\left(\mathrm{SnCl}_{2}\right.$, Singh et al. 2006) and sodium sulfide $\left(\mathrm{Na}_{2} \mathrm{~S}\right)$ (Russell et al. 2006) can be added to reduce Tc and rhenium $(\mathrm{Re})\left(\mathrm{Re}\right.$ is frequently used as a surrogate for $\mathrm{Tc}$ ) from the +7 oxidation state $\left(\mathrm{TcO}_{4}{ }^{-}\right)$to the less mobile +4 oxidation state [Tc(IV)]. Blast furnace slag also helps with this reduction. Sodium sulfide addition will also result in the formation of more insoluble sulfide forms of mercury $(\mathrm{HgS})$ and chromium (CrS) (Russell et al. 2006).

Singh et al. (2006) studied the effectiveness of Ceramicrete for immobilizing ${ }^{99} \mathrm{Tc}$ in a waste stream generated by a process for separating ${ }^{99} \mathrm{Tc}$ from Hanford Site tank supernatant. A typical composition of this waste solution is $1 \mathrm{M} \mathrm{NaOH}, 1 \mathrm{M}$ ethylenediamine, $0.005 \mathrm{M} \mathrm{Sn}(\mathrm{II})$, and Tc as high as $150 \mathrm{ppm}$ or $0.0015 \mathrm{M}$. Two approaches were used to test Ceramicrete with this waste. In the first approach, the aqueous waste was stabilized directly by adding $38 \mathrm{wt} \%$ fly ash and $2-3 \mathrm{wt} \% \mathrm{SnCl}_{2}$ to the Ceramicrete binder. The optimal waste loading was $36 \mathrm{wt} \%$ (wet basis). The concentrations of ${ }^{99} \mathrm{Tc}$ in these waste forms ranged from 20 to $150 \mathrm{ppm}$. In the second approach, the role of $\mathrm{SnCl}_{2}$ was investigated by adding

$\mathrm{SnCl}_{2}$ to precipitate ${ }^{99} \mathrm{Tc}$ from the waste solution prior to fabricating the waste form. In this approach, the ${ }^{99} \mathrm{Tc}$ concentrations in the waste forms were as high as $900 \mathrm{ppm}$. The waste forms were prepared in an anoxic nitrogen atmosphere. Waste form performance was established through various strength, leaching, and durability tests. Long-term leaching studies (using ANS 16.1, ANSI/ANS 2008), showed leachability indices between 11 and 14 for ${ }^{99} \mathrm{Tc}$ under ambient conditions. The normalized leach rate (using the PCT, ASTM 2008a) for seven days for ${ }^{99} \mathrm{Tc}$ was as low as $1.1 \times 10^{3} \mathrm{~g} / \mathrm{m}^{2} \mathrm{~d}$. The waste forms exhibited a compressive strength of $\sim 30 \mathrm{MPa}$ and were durable in an aqueous environment. Containment of ${ }^{99} \mathrm{Tc}$ in 
phosphate-bonded ceramics is believed to be due to a combination of an appropriate reducing environment (determined from Eh-pH measurements) and microencapsulation in a dense matrix.

\subsection{Fluidized Bed Steam Reforming Aluminosilicate}

At the Hanford Site, the FBSR process was evaluated both as a supplemental technology for treating and immobilizing Hanford LAW radioactive tank waste and for treating secondary wastes from the WTP pretreatment and LAW vitrification processes. The process has been demonstrated at a pilot scale with nonradioactive simulants of Hanford Envelope C (AN-107) (Jantzen 2002; Pareizs et al. 2005), and Envelope A (saltcake) tank wastes (Olson et al. 2004; TTT 2009), and with a simulant of the LAW melter off-gas recycle (Jantzen et al. 2011). It has also been demonstrated with the Idaho National Laboratory (INL) sodium-bearing waste to produce an alkali-aluminosilicate waste form (Ryan et al. 2008). Most testing has been conducted with Re as a surrogate for Tc (Pierce et al. 2014; Neeway et al. 2014b), although some tests have been performed with the Bench-Scale Reformer at SRNL with actual Hanford tank waste (Jantzen et al. 2013). A comprehensive report with data from experiments conducted mostly at SRNL and some at Pacific Northwest National Laboratory (PNNL) over the last years will be published soon (Jantzen et al. 2014). These recent publications and the bibliographical references therein are a valuable source of information about FBSR waste form production and performance testing in support of Hanford supplemental LAW immobilization technology selection. Two additional PNNL reports were also published recently. The first one was the FBSR data package, which identified, evaluated, and summarized existing information in the open literature to be used in the down-selection process to select waste forms for stabilizing and solidifying the liquid secondary wastes at Hanford (Qafoku et al. 2011). The second report includes a set of experimental data on FBSR performance testing performed at PNNL (Pires et al. 2011).

The FBSR aluminosilicate waste form has two main components: a granular product and a monolithic encapsulating material. Production of the FBSR waste form begins with a granular product formed when radioactive waste is introduced with kaolin clay and coal into a bed fluidized with steam at $600^{\circ}$ to $800^{\circ} \mathrm{C}$ and near-ambient pressure. In the steam environment, the clay reacts with $\mathrm{Na}, \mathrm{K}$, and $\mathrm{Cs}$ to form new sodium aluminosilicate mineral phases such as nepheline, sodalite, and nosean. The waste-feed droplets coat the bed particles and rapidly dry. The resulting dry granular product is then encapsulated in a binder material to produce a monolithic form to limit dispersibility and to provide some structural integrity for subsidence prevention in the disposal facility. Various tests have been performed to investigate potential binders for monolith formation, including cements, high-aluminum cements, geopolymers, hydroceramic cements, and Ceramicrete (TTT 2009).

Extensive solid-phase characterization and chemical durability testing has been conducted on the FBSR granular and monolithic products (Williams et al. 2014). The solid-phase characterization efforts include moisture content and surface area measurements (using the Brunauer-Emmett-Teller method), as well as mineralogical determination using X-ray diffraction (XRD) and scanning electron microscopy combined with energy dispersive spectrometry. XANES and extended X-ray absorption fine structure (EXAFS) have also been used in the past to study the valence state and molecular-scale composition of contaminants of interest sorbed or incorporated into solid phases. A variety of chemical durability tests have been conducted such as the PCT (ASTM 2008a), PUF test (McGrail et al. 2001), ASTM Method C1308 diffusion testing (ASTM 2008b), TCLP (EPA 1992) and the SPFT test (McGrail et al. 2000), to 
study and determine parameters of chemical durability of the FBSR waste forms (either granular and/or monolithic products), and retention and release of radionuclides and constituents of concern.

The primary mineral product from the FBSR process is a multiphase mineral granular product that is composed of at least three sodium aluminosilicate minerals. These are Na-Al-Si feldspathoid minerals, primarily nepheline with minor amounts of sodalite and nosean. Nepheline is the basic sodium aluminosilicate mineral with the formula $\mathrm{Na}_{2} \mathrm{O}-\mathrm{Al}_{2} \mathrm{O}_{3}-2 \mathrm{SiO}_{2}$. When an anion is incorporated in the cage structure of nepheline, a mineral in the sodalite group is formed. Many monovalent cations and anions, as well as divalent anions, can be substituted into the structure, making this a robust mineral and a good scavenger in terms of contaminant incorporation. Two important anions in the Hanford tank wastes are $\mathrm{SO}_{4}{ }^{2-}$ and $\mathrm{TcO}_{4}{ }^{-}$. When $\mathrm{SO}_{4}{ }^{2-}$ is incorporated as the anion into the crystal structure, it forms the mineral known as nosean $\left(\mathrm{Na}_{2} \mathrm{O}-\mathrm{Al}_{2} \mathrm{O}_{3}-2 \mathrm{SiO}_{2}-\mathrm{Na}_{2} \mathrm{SO}_{4}\right)$. In a similar way, it is now believed that $\mathrm{TcO}_{4}{ }^{-}$may be incorporated into the cage structure as well. Evidence of this was first shown through XRD and Raman spectroscopy measurements where $\mathrm{ReO}_{4}{ }^{-}$, a surrogate for radioactive $\mathrm{TcO}_{4}{ }^{-}$, was shown to incorporate into the sodalite structure (Mattigod et al. 2006). In a more recent publication, Re has been shown to be present in the sodalite cages synthesized during the FBSR process using EXAFS data (Pierce et al. 2014) Finally, indirect evidence that Tc is sequestered in sodalite (or other FBSR minerals) and occupies the same site as Re has been implied through the concomitant release following similar trends of these two elements, in a series of SPFT experiments performed recently at PNNL (Neeway et al. 2014a).

A series of durability tests of the granular and monolithic product has also been performed. The FBSR waste form has been shown to meet the Universal Treatment Standards in 40 CFR 268, Land Disposal Restrictions, as measured with the TCLP test. As with any waste form, if the concentrations of the constituents of concern are too high, the waste form will not pass the TCLP test. However, data from experiments conducted at PNNL have shown that, at the expected concentrations of hazardous components in the secondary wastes, the FBSR product will easily pass the TCLP (Williams et al. 2014). Data have also shown that the FBSR waste form monoliths passed the 500-psi compressive strength requirement (Williams et al. 2014). Candidate binders include cements, geopolymers, and Ceramicrete. Both the granular and monolith FBSR products have been shown to pass the PCT response requirements, as well (Williams et al. 2014).

A series of SPFT tests has been performed on nonradioactive granular materials and granular materials encapsulated in a geopolymer binder produced at the engineering and bench scales. At least one test has also been performed on a granular product produced at the bench scale with actual radioactive Hanford tank waste. SPFT tests were conducted at $40^{\circ} \mathrm{C}$ for durations up to 2 months with a flow-through solution buffered at $\mathrm{pH}$ 9. The forward reaction rate of the nonradioactive granular product based on Re release, which again is a nonradioactive surrogate commonly used for Tc in experiments of different types, was calculated to be $(19 \pm 5.3) \times 10^{-4} \mathrm{~g} / \mathrm{m}^{2} \mathrm{~d}$ for the engineering-scale product and $(24 \pm 6.5) \times 10^{-4} \mathrm{~g} / \mathrm{m}^{2} \mathrm{~d}$ for the bench-scale product. The resulting nonradioactive monoliths showed forward reaction rates based on Re release of $(9.1 \pm 2.4) \times 10^{-4} \mathrm{~g} / \mathrm{m}^{2} \mathrm{~d}$ for the engineering-scale material and $(19 \pm 5.1) \times 10^{-4} \mathrm{~g} / \mathrm{m}^{2} \mathrm{~d}$ for the bench-scale material, showing no significant difference in specific corrosion rate under the conditions tested. Finally, an FBSR granular product created at the bench scale using actual Hanford LAW gave forward release rates of $(16 \pm 6.2) \times 10^{-4} \mathrm{~g} / \mathrm{m}^{2} \mathrm{~d}$ for Tc and $(11 \pm 5.4) \times 10^{-4} \mathrm{~g} / \mathrm{m}^{2} \mathrm{~d}$ for Re. These values are 1 to 2 orders of magnitude lower than forward rates calculated using potential waste glasses, although this does not necessarily translate to improved performance in the IDF. 
Finally, to demonstrate the durability of the product in the unsaturated IDF at Hanford, PUF tests have been performed using one of the FBSR materials. The PUF tests are usually conducted under controlled unsaturated, controlled temperature conditions, which allow for the accelerated weathering of the minerals present in waste forms, including radioactive waste forms. The system maintains hydraulically unsaturated conditions, thus mimicking the open-flow and transport properties that will be present at the IDF. Results of the experiments show a trend of decreasing effluent concentration as a function of time for several of the elements released from the FBSR material, including $\mathrm{Na}, \mathrm{Si}, \mathrm{Al}$, and Cs. However, the elements I and Re showed a steady release throughout the test period of one year. This result suggests that the aqueous concentrations of these elements are controlled by a dissolving solid phase.

\subsection{Synroc}

Synroc is a multiphase ceramic that incorporates components of radioactive waste into its crystal structure. Naturally occurring rocks have isolated radioactive materials for long times (as long as the estimated age of the earth). The aim of Synroc is to replicate this ability by converting waste into the crystalline structure of simulated rock minerals known to last over such long time scales (Vance et al. 1997).

Synroc can incorporate high concentrations of Cs (primarily in hollandite) and strontium (Sr) (primarily in perovskite) and is thermally robust, with the ability to withstand high radiogenic heat output. To achieve maximum cost savings and to optimize performance, the Synroc waste forms are tailored to suit the particular characteristics of the nuclear waste to be immobilized rather than adopting a single one-size-fits-all approach.

Different types of Synroc waste forms (different ratios of component minerals and specific processing parameters; e.g., hot isostatic pressing (HIP) pressures and temperatures, etc.) can be developed for the immobilization of different types of waste. A number of mineral phases including zirconolite and perovskite, pyrochlore, brannerite, and a broad solid solution of [Ti,Pu, $\mathrm{U}, \mathrm{Zr}, \mathrm{Hf}^{-} \mathrm{O}_{2}$ (sometimes called fluorite after the structural form) can accommodate actinides. The exact proportions of the main phases vary depending on the HLW composition. For example, Synroc-C is designed to contain about $20 \mathrm{wt} \%$ of calcined HLW and it consists of approximately $30 \mathrm{wt} \%$ hollandite; $30 \mathrm{wt} \%$ zirconolite; $20 \mathrm{wt} \%$ perovskite, and $20 \mathrm{wt} \%$ titanium (Ti) oxides and other phases. Immobilizing weapons-grade plutonium or transuranic wastes instead of bulk HLW may essentially change the Synroc phase composition to a primarily zirconolite-based or a pyrochlore-based ceramic. The starting precursor for Synroc-C fabrication contains $\sim 57 \mathrm{wt} \% \mathrm{TiO}_{2}$ and $2 \mathrm{wt} \%$ metallic Ti. The metallic Ti provides reducing conditions during ceramic synthesis and helps decrease volatilization of radioactive Cs (Burakov et al. 2010). Use of HIP to fabricate Synroc waste forms is effective for sequestering volatile radionuclides (such as I, Tc, and Cs) and reduces the demand for off-gas treatment.

Technetium separated out during decontamination of liquid Hanford wastes can be incorporated in

hot-pressed Synroc prepared under reducing conditions. Its leach resistance is good (approximately $10^{-3}$ $\mathrm{g} / \mathrm{m}^{2} \mathrm{~d}$ at $70^{\circ} \mathrm{C}$ ), and can be improved by alloying with iron-group metals. With a choice of "neutral" $\left[\mathrm{P}\left(\mathrm{O}_{2}\right)\right.$ to approximately $10^{-4}$ atm., near the $\mathrm{Ni} / \mathrm{NiO}$ buffer] hot-pressing conditions, Tc can also be incorporated as $\mathrm{Tc}^{4+}$, substituting for $\mathrm{Ti}^{4+}$ in the ceramic phases, which are expected to be highly leach-resistant (Vance et al. 1997). 


\subsection{Technetium-Specific Immobilization Methods}

This section describes waste forms developed and tested for specifically for Tc. Included are iron-technetium oxides, metal alloys, Tc oxides, framework aluminosilicate minerals, titanates, apatites, layered double hydroxides (LDH), and sulfur-based aerogels. Several of these immobilization methods originated as techniques for separating Tc from aqueous solution. As such, their development for application as waste forms may be just in its infancy.

\subsection{Iron-Technetium Oxides}

One promising ${ }^{99} \mathrm{Tc}$-specific waste form that is under investigation uses ferric (oxy)hydroxide minerals such as goethite, ferrihydrite, magnetite, and maghemite that appear to have the ability to substitute the ${ }^{99} \mathrm{Tc}(\mathrm{IV})$ cation atom for Fe(III) cation sites in the crystalline ferric oxide lattice structure. During a comprehensive review of Tc geochemistry, Icenhower et al. $(2008,2009,2010)$ noted that the $\mathrm{Tc}(\mathrm{VII})$ in solution could be rapidly reduced when the solution contacts solids that contain $\mathrm{Fe}(\mathrm{II})$ adsorbed to the solid's surface or when the solid contains Fe(II) structural atoms. When Fe(II) is sorbed onto other mineral phases, especially iron oxyhydroxides, surface-mediated heterogeneous catalysis becomes important and reduction of Tc(VII) to Tc(IV) takes place rapidly above $\mathrm{pH} 6$ (Zachara et al. 2007; Peretyazhko et al. 2008) and yields the relatively insoluble $\mathrm{Tc}(\mathrm{IV}) \mathrm{O}_{2} \cdot \mathrm{xH}_{2} \mathrm{O}$ solid.

$\mathrm{Tc}(\mathrm{IV})$ has a crystal radius that is quite similar to that of $\mathrm{Fe}(\mathrm{III})$, as shown in Table 5.1. Table 5.1 also shows the crystal radii of Re, which is often used as an analog for Tc because it is not radioactive and hence is easier to use. Note that the ferric cation has a sixfold coordination and in its high-spin state has a radius of 78.5 picometers $(\mathrm{pm})$, and that the $\mathrm{Tc}^{+4}$ cation also has sixfold coordination and a radius of $78.5 \mathrm{pm}$. Rhenium in the +4 valence state also has sixfold coordination and a slightly smaller radius of $77 \mathrm{pm}$. Thus, it is plausible that the Tc(IV) atom can substitute for $\mathrm{Fe}(\mathrm{III})$ in the lattice structure of goethite, which is an Fe(III) iron oxyhydroxide. There is a difference in charge between the Fe(III) and the Tc(IV) atoms that will lead to some distortion in the crystal structure. Goethite is a very stable mineral in subsurface oxic environments and is not particularly prone to reduction or dissolution over a wide range of near-surface environments. Goethite is resistant to chemical weathering because the hydrogen and oxygen atoms in the goethite structure are resistant to exchange with the environment for up to 50 million years (Navrotsky et al. 2008). Geckeis et al. (2012) found that ${ }^{99} \mathrm{Tc}(\mathrm{IV})$ tends to be fully compatible with incorporation into the hematite lattice. Using quantum mechanics molecular modeling, Skomurski et al. (2010) also concluded that Tc(IV) cations could substitute into hematite lattice sites in place of Fe. Hematite is another stable ferric oxide with mineral formula $\alpha-\mathrm{Fe}_{2} \mathrm{O}_{3}$.

When $\mathrm{Tc}(\mathrm{IV})$ cations are associated with structural Fe(III) oxyhydroxides, the resistance to reoxidation appears to be subject to the limitation of oxygen diffusion into the oxyhydroxides. Therefore, optimal immobilization of Tc appears to be the result of incorporation into a mineral host that resists the diffusion of oxygen into its structure. The mobility of $\mathrm{Tc}$ in the environment may be best controlled by sequestration into crystalline oxyhydroxide phases that are stable in the disposal system environment, including ferrihydrite, goethite, and perhaps hematite, maghemite, and magnetite. If such Tc incorporation into these solid phases takes place, then the mobility of Tc may depend on the stability of the host phase and not necessarily upon the reoxidation kinetics. 
Table 5.1. Crystal Radii (in picometers) and Coordination Numbers for Iron, Rhenium, and Technetium, from Yang et al. (2006)

\begin{tabular}{|c|c|c|c|}
\hline Element & Cation & Coordination Number ${ }^{a}$ & Radius (pm) \\
\hline \multirow[t]{4}{*}{ Iron } & $\mathrm{Fe}^{2+}$ & 6, LS & 75 \\
\hline & & 6, HS & 92 \\
\hline & $\mathrm{Fe}^{3+}$ & 6, LS & 69 \\
\hline & & 6, HS & 78.5 \\
\hline \multirow[t]{3}{*}{ Rhenium } & $\operatorname{Re}^{4+}$ & 6 & 77 \\
\hline & $\mathrm{Re}^{7+}$ & 4 & 52 \\
\hline & & 6 & 67 \\
\hline \multirow[t]{3}{*}{ Technetium } & $\mathrm{Tc}^{4+}$ & 6 & 78.5 \\
\hline & $\mathrm{Tc}^{7+}$ & 4 & 51 \\
\hline & & 6 & 70 \\
\hline
\end{tabular}

${ }^{\mathrm{a}}$ The coordination number refers to the number of associated ligands and LS and HS stand for "low-spin” and "high spin” configurations

Um et al. (2010, 2011a, 2012, and 2013; Westsik et al. 2011) have been conducting experimental studies on sequestering Tc in goethite and other iron oxide solid phases. Their first studies showed that goethite could sequester significant amounts ( $>90 \%$ of the initial Tc mass) of Tc present in simple and caustic brine simulants as long as additional aqueous $\mathrm{Fe}(\mathrm{II})$ was added and the $\mathrm{pH}$ of the slurry was adjusted to neutral to mildly caustic conditions. In a slurry of goethite, dissolved Fe(II), and $\mathrm{Tc}(\mathrm{VII})$-laden waste simulants, Tc concentrations in solution decreased immediately when the slurry $\mathrm{pH}$ was raised above 7.0. The total amount of Tc present in the final solid as determined by acid digestion showed a high degree of Tc sequestration, $90 \%$ to $100 \%$, in the final Tc-goethite solids.

The resultant $\mathrm{Fe}(\mathrm{II})$-treated goethite removed Tc from caustic briny waste solutions; however, the presence of anions other than hydroxide and carbonate in the waste streams, especially $\mathrm{PO}_{4}{ }^{3-}$ and, to a lesser extent $\mathrm{SO}_{4}{ }^{2-}$, decreases the Tc-removal efficiency slightly. It was also discovered that, after the mixing of the caustic waste simulants with the goethite and aqueous Fe(II) and separating the Tc-laden hydrous ferric oxide; there was a small amount of Tc re-release from the solid via Fe oxide dissolution at $\mathrm{pH}$ conditions above 10. Thus, the final disposal environment of the Tc-laden ferric oxide is optimal in subsurface environments with a pH below 10, or additional ferric iron should be added to keep the disposal saturated with dissolved iron.

It was also discovered that the dominant final mineral present in Tc-goethite slurries at the end of processing in many tests was magnetite. In tests where an additional Fe(III) armoring step was performed, after the Tc was reduced and incorporated into the ferric (oxy)hydroxide, by adding soluble $\mathrm{Fe}(\mathrm{III})$ in a slightly acidic solution and then adding additional sodium hydroxide to raise the $\mathrm{pH}$ and promote additional ferric oxide precipitation, the outer surfaces of the solids were predominately goethite. No Fe-carbonate minerals were found in any Tc-goethite test solids, even in the experiments conducted with Tc-laden off-gas scrubber waste simulant containing high concentrations of ammonium carbonate. 
Powdered solids and monolithic cylindrical pellets of the final Tc-goethite product were exposed to dilute leaching solutions (buffered at $\mathrm{pH}$ values of 4, 7, and 10), synthetic Hanford vadose zone pore water $(\mathrm{pH}=7.2$ and ionic strength $=0.05 \mathrm{M})$, and IDF glass leachate simulant $(\mathrm{pH}=9.7$ and ionic strength $=1.67 \mathrm{M}$ ). The latter two solutions simulate geochemical conditions in the IDF facility. Although Tc-goethite final solids were exposed to these various leaching fluids for up to two years, the reduced $\mathrm{Tc}(\mathrm{IV})$ was not reoxidized to $\mathrm{Tc}(\mathrm{VII})$. One pellet was first stored in air for months before being leached. In the circumneutral Hanford pore water simulant, the concentration of leached Tc from the Tc-goethite pellet was very low, and an effective diffusion coefficient of $6.15 \times 10^{-11} \mathrm{~cm}^{2} / \mathrm{s}$ was calculated (Um et al. 2012).

For powdered Tc-goethite final product, the amount of Tc that leaches per gram of final solid product is quite low ( $<3 \mu \mathrm{g} \mathrm{Tc} / \mathrm{g}$ of solid) for all the leachants, and there is little increase in Tc concentration over time. The sample with the lowest leaching properties had a final treatment with precipitation of additional ferric oxide (goethite) onto its surfaces after sequestering the Tc. This post-Tc-reduction/incorporation step forms a physical armoring layer that provides a second barrier to leaching and reoxidation of Tc(IV) (Um et al. 2011a).

Um et al. (2013) showed that $\mathrm{Fe}(\mathrm{OH})_{2}(\mathrm{~s})$ readily reduced and then sequestered Tc and transformed to a mixture of magnetite, maghemite, ${ }^{1}$ and goethite even at room temperature and circumneutral $\mathrm{pH}$ conditions. Removal of ${ }^{99} \mathrm{Tc}$ from solution by $\mathrm{Fe}(\mathrm{OH})_{2}(\mathrm{~s})$ was fast, and more than $95 \%$ of the initial ${ }^{99} \mathrm{Tc}$ $\left(10^{-5} \mathrm{M}\right)$ was removed from $\mathrm{Tc}(\mathrm{VII})$-spiked distilled water even without aqueous Fe(II) addition. All that was required was to mix the slurry for up to seven days at either of the $\mathrm{pHs}$ and temperatures mentioned. $\mathrm{Fe}(\mathrm{OH})_{2}(\mathrm{~s})$ readily oxidizes to form magnetite $\left(\mathrm{Fe}_{3} \mathrm{O}_{4}\right)$ when reacted with $\mathrm{H}_{2} \mathrm{O}$ even in anoxic conditions. $\mathrm{The} \mathrm{Fe}(\mathrm{OH})_{2}$ (s) can provide aqueous $\mathrm{Fe}(\mathrm{II})$ as well as $\mathrm{Fe}(\mathrm{II})$ solid surface sites (the heterogeneous catalyst route) to reduce $\mathrm{Tc}(\mathrm{VII})$ to $\mathrm{Tc}(\mathrm{IV})$. When varying the starting $\mathrm{Tc}(\mathrm{VII})$ concentration in the slurry from $10^{-5}$ to $10^{-4}$ and finally to $10^{-3} \mathrm{M}$ in a constant mass of $\mathrm{Fe}(\mathrm{OH})_{2}(\mathrm{~s})$ slurry and without adding aqueous $\mathrm{Fe}$ (II) for the $\mathrm{pH} 12$ and high-temperature condition, 97\%, 77 to $86 \%$, and 64 to $65 \%$ of the Tc was removed, respectively, from the slurries after seven days of reaction. It is expected that similar (perhaps slightly lower) Tc(VII) removal rates would be found at lower temperatures and at $\mathrm{pH}$ values between 7 and 12. The results suggest that, for a fixed mass of starting $\mathrm{Fe}(\mathrm{OH})_{2}$, there is a limit to the amount of $\mathrm{Tc}(\mathrm{VII})$ that can be removed. For more concentrated $\mathrm{Tc}(\mathrm{VII})$ solutions, more starting $\mathrm{Fe}(\mathrm{OH})_{2}$ could be used to increase the percentage of $\mathrm{Tc}(\mathrm{VII})$ removed.

The final Tc-ferric oxyhydroxide transformation product when starting from ferrihydrite ${ }^{2}$ was solely goethite in most of the slurry tests over the range of $\mathrm{pHs}$ and temperatures used. It was noticed that final Tc sequestering results from both $\mathrm{Fe}(\mathrm{OH})_{2}(\mathrm{~s})$ and ferrihydrite substrates show that the high slurry $\mathrm{pH}$ and high-temperature conditions favor more goethite formation and slightly higher Tc removal. For the ferrihydrite tests performed in Um et al. (2013), only the initial $10^{-5} \mathrm{M} \mathrm{Tc}$ (VII) condition was tested and aqueous $\mathrm{Fe}$ (II) addition was used during the Tc(VII) sequestration process. The removal rate for Tc(VII) when aqueous $\mathrm{Fe}$ (II) was added to the ferrihydrite slurry was $\sim 90 \%$. If no additional aqueous $\mathrm{Fe}(\mathrm{II})$ was

\footnotetext{
${ }^{1}$ Maghemite $\left(\gamma-\mathrm{Fe}_{2} \mathrm{O}_{3}\right)$ is an $\mathrm{Fe}(\mathrm{II})$-deficient magnetite; magnetite is a mixed $\mathrm{Fe}(\mathrm{II}) / \mathrm{Fe}(\mathrm{III})$ oxide mineral, $\mathrm{Fe}_{3} \mathrm{O}_{4}$, with one $\mathrm{Fe}(\mathrm{II})$ and two $\mathrm{Fe}(\mathrm{III})$ atoms per unit cell.

${ }^{2}$ Ferrihydrite is a precursor material that transforms into goethite after reacting with a caustic pH slurry in an oven at $80^{\circ} \mathrm{C}$. However, in nature, over geologic time frames, the ferrihydrite-to-goethite transformation can occur at lower temperatures and circumneutral $\mathrm{pH}$.
} 
added during the ferrihydrite slurry interaction with Tc(VII) solutions, there was no Tc removal under either $\mathrm{pH}$ or temperature condition. In earlier work, Um et al. (2010) used ferrihydrite as a starting substrate to remove $\mathrm{Tc}(\mathrm{VII})$ from slightly basic $(\mathrm{pH}=9)$ brine secondary waste simulant that contained $3.2 \times 10^{-6} \mathrm{M} \mathrm{Tc}(\mathrm{VII})$. After addition of aqueous $\mathrm{Fe}(\mathrm{II})$ and sodium hydroxide to bring the final slurry $\mathrm{pH}$ up to $\sim 12$, about $80 \%$ of the Tc was removed by the final iron oxyhydroxide solid.

When starting with magnetite as the starting iron oxide after the slurry reactions were finished, there was very limited transformation only for the high-pH and -temperature condition, where small amounts of maghemite and goethite formed. In addition, negligible $\mathrm{Tc}(\mathrm{VII})$ removal $(<5 \%)$ from solution was found in magnetite slurry without aqueous $\mathrm{Fe}(\mathrm{II})$ addition at either temperature and either final slurry $\mathrm{pH}$. The ability of the magnetite slurry to remove Tc(VII) from solution using the $\mathrm{Fe}$ (II) addition step to promote more precipitation has not been tested yet.

The results of the second suite of tests indicate that adding aqueous Fe(II) still helps remove the ${ }^{99} \mathrm{Tc}$ (VII) from solution, but the bulk of the Tc(VII) removal is considered to result from the mineral transformation [i.e., the highly reactive $\mathrm{Fe}(\mathrm{OH})_{2}(\mathrm{~s})$ transformed to maghemite, magnetite, and goethite with a concomitant removal of Tc(VII)]. Ferrihydrite can also be used as a starting sequestering solid because it also transforms to goethite. The advantage of starting with ferrihydrite is that ferrihydrite is easier to prepare than goethite when laboratory quantities of ferric oxides are used in $\mathrm{Tc}$ (VII) sequestration testing. However, in very limited testing, Um et al. (2010) also found that commercially available goethite removed Tc(VII) from waste simulants the same as laboratory-prepared goethite. A key finding of these studies is that $\mathrm{Fe}(\mathrm{OH})_{2}$ is the most reactive starting substrate for removal of $\mathrm{Tc}(\mathrm{VII})$ from waste simulants. There is no need for adding additional Fe(II) solution to slurries of the iron oxyhydroxides and waste simulants to effect Tc(VII) removal (although adding the aqueous $\mathrm{Fe}(\mathrm{II})$ does improve the removal somewhat). However, $\mathrm{Fe}(\mathrm{OH})_{2}$ is highly reactive when exposed to air or oxygenated solutions, leading to conversion to magnetite, maghemite, and goethite. With time and continued exposure to oxygen, goethite is the final mineral.

In conclusion, the testing to date suggests that the final reaction products (either a mixture of maghemite, magnetite, and goethite, but with goethite likely the major host $)^{3}$ can sequester Tc in structural lattice sites and minimize Tc reoxidation to the mobile $\mathrm{Tc}(\mathrm{VII})$ pertechnetate species. The sequestered Tc(IV) can be made even more resistant to oxidation by adding an additional goethite armoring layer.

The work of Um et al. (2010, 2011a, 2012, 2013) has been a good preliminary effort but throughout the documents, they stress that more detailed experiments (both Tc sequestration and subsequent longterm leaching) and solid-phase characterization studies using various state-of-the-art techniques are needed. Note also that the final technetium-iron oxide minerals are fine-grained particles that would require some form of encapsulation, mixing with a binder, isostatic pressing into pellets, or disposal in high-integrity containers to be a non-dispersible waste form.

\footnotetext{
${ }^{3}$ Recall that using ferrihydrite as the starting substrate generally yields solely goethite as the final Tc sequestering agent.
} 


\subsection{Metal Alloys}

Metal alloy waste forms are being developed as a means of dispositioning fuel cladding and hardware and for immobilization of undissolved solids remaining after dissolution of stainless-steel-clad fuels in molten salts. The epsilon metal waste form is being developed for the undissolved solids from aqueous dissolution of oxide fuels and reduced soluble Tc.

\subsubsection{Epsilon Metal}

Epsilon metal ( $\varepsilon$-metal) is an alloy of $\mathrm{Mo}, \mathrm{Pd}, \mathrm{Rh}, \mathrm{Ru}$, and $\mathrm{Tc}$ metals (Crum et al. 2013). It forms during the irradiation of nuclear fuel when these elements migrate to the uranium grain boundaries. The alloy remains as an undissolved solid during the dissolution of used fuel. The $\varepsilon$-metal alloy is attractive as a waste form because remnants of the alloy were found at the natural reactor sites in Gabon, Africa (Utsunomiya and Ewing 2006; Strachan et al. 2010). Analyses of the site found that all of the ${ }^{99} \mathrm{Tc}$ decayed to ${ }^{99} \mathrm{Ru}$ before significant dissolution or migration in the near-surface environment, suggesting sufficiently high performance for small $(\leq 10 \mu \mathrm{m})$ particles.

There does not appear to be a single composition for the $\varepsilon$-metal alloy. Rather, it depends on the fuel burnup. Table 5.2 shows the composition of $\varepsilon$-metal alloys used by different researchers investigating the alloy as a waste form (Cui et al. 2001; Strachan et al. 2010; Crum et al. 2013).

Table 5.2. Compositions Used in Testing of Epsilon Metal as a Waste Form

\begin{tabular}{|c|c|c|c|c|c|}
\hline & & \multicolumn{2}{|c|}{ Strachan et al. ${ }^{(a)}$} & Crum et al. ${ }^{(\mathbf{b})}$ & Cui et al. ${ }^{(c)}$ \\
\hline Element & $\begin{array}{l}\text { Melting } \\
\text { Point, }{ }^{\circ} \mathrm{C}\end{array}$ & $100 \mathrm{MWd} / \mathrm{t}$ & $25 \mathrm{MWd} / \mathrm{t}$ & Baseline $^{\mathbf{b}}$ & \\
\hline Mo & 2623 & $18.4 \%$ & $18.4 \%$ & $35.4 \%$ & $46 \%$ \\
\hline $\mathrm{Tc}$ & 2204 & $9.2 \%$ & $11.2 \%$ & $17.2 \%$ (as $\mathrm{Re})$ & - \\
\hline $\mathrm{Ru}$ & 2337 & $28.3 \%$ & $27.1 \%$ & $28 \%$ & $29 \%$ \\
\hline $\mathrm{Rh}$ & 1963 & $3.1 \%$ & $5.6 \%$ & $4.7 \%$ & $4 \%$ \\
\hline $\mathrm{Pd}$ & 1552 & $41.0 \%$ & $37.6 \%$ & $14.7 \%$ & $21 \%$ \\
\hline
\end{tabular}

Cui et al. (2001) estimated a Tc leach rate from the alloy based on the normalized leach rates of a Mo, $\mathrm{Ru}, \mathrm{Rh}$, and Pd alloy and on the redox potentials of the four metals and Tc. They estimated the Tc leach rate to be $4 \times 10^{-7} \mathrm{~g} / \mathrm{cm}^{2} \mathrm{~d}$ in air-saturated conditions and $4 \times 10^{-9} \mathrm{~g} / \mathrm{cm}^{2} \mathrm{~d}$ under reducing conditions.

Much of the recent work on the $\varepsilon$-metal alloy has focused on identification and characterization of methods for producing the alloy. Among the methods considered are arc melting, induction melting (inert gas or vacuum), hot uniaxial pressing, HIP, spark plasma sintering (SPS), microwave sintering, and furnace melting (Strachan et al. 2010; Rohatgi and Strachan 2011). Cui et al. (2001) used a cold-crucible levitation melting apparatus to conduct melting at $1800^{\circ} \mathrm{C}$ in an argon atmosphere. Crum et al. (2013) conducted small-scale tests with commercially available SPS, HIP, and microwave sintering processes. 
Processing temperatures were in the range of $1500^{\circ}$ to $1550^{\circ} \mathrm{C}$. These scoping tests showed SPS and HIP to be the more suitable processes with respect to $\varepsilon$-metal alloy preparation.

\subsubsection{Stainless-Steel-Based Alloys}

Stainless steel/zirconium metal alloys were originally developed for treating fast-reactor fuel alloys and the associated wastes (McDeavitt et al. 1998). An electrometallurgical treatment process was developed for the uranium metal fuels used in the Experimental Breeder Reactor-II and other experimental reactors. The electrometallurgical process resulted in a recovered actinide metal product and two waste streams, including a molten salt phase with most of the fission products and actinides, and an electrochemically inert solid phase with cladding hull material from the spent fuel assemblies and noble metal fission products including $\mathrm{Ru}, \mathrm{Rh}, \mathrm{Pd}, \mathrm{Nb}, \mathrm{Mo}, \mathrm{Zr}$, and Tc. Formations of stainless steel/zirconium alloys were selected for the treatment of this waste stream (McDeavitt et al. 1998).

Stainless steel and Zircaloy are typical components of nuclear fuel cladding and are a waste stream from fuel reprocessing facilities. Work has focused on blends of these materials as a means of volume reduction and formation of corrosion-resistant waste forms (Abraham et al. 1996). Two alloys were selected for development and characterization: a stainless steel - $15 \mathrm{wt} \%$ zirconium (SS-15Zr) mix and a zirconium-8 wt\% stainless steel (Zr-8SS) mix (McDeavitt et al. 1998). These two alloys were prepared by melting in inert-atmosphere furnaces at $1600^{\circ} \mathrm{C}$. With the $\mathrm{SS}-15 \mathrm{Zr}$ alloy, the stainless steel melts first and wets the $\mathrm{Zr}$, causing it to melt at a temperature lower than its nominal melting point of $1855^{\circ} \mathrm{C}$ (Frank et al. 2007). The SS-15Zr alloy has been prepared in sizes ranging from approximately 15 grams to 1 to $3 \mathrm{~kg}$. Larger $60 \mathrm{-kg}$ ingots have been produced as part of a waste form qualification effort (Frank et al. 2007). A full-scale ingot of $43.2 \mathrm{~kg}$ was recently produced with actual metal fuel cladding wastes (Westphal et al. 2013).

Phase characterization of the SS-15Zr alloy shows a mix of ferritic iron $(\alpha-\mathrm{Fe})$, austenitic iron $(\gamma-\mathrm{Fe})$, a Laves intermetallic phase [ $\mathrm{Zr}(\mathrm{Fe}, \mathrm{Cr}, \mathrm{Ni})_{2+\mathrm{x}}$, and $\mathrm{Zr}_{6} \mathrm{Fe}_{23}$ type] (McDeavitt et al. 1998). This phase composition is similar to the $\mathrm{Fe}-\mathrm{Zr}$ binary phase diagram with a eutectic at $1325^{\circ} \mathrm{C}$ between $\mathrm{Fe}$ and $\mathrm{ZrFe}_{2}$. Phase characterization of the $\mathrm{Zr}-8 \mathrm{SS}$ alloy shows a mix of $\alpha-\mathrm{Zr}, \mathrm{Zr}(\mathrm{Fe}, \mathrm{Cr})_{2}$, and $\mathrm{Zr}_{2}(\mathrm{Fe}, \mathrm{Ni})$. In the SS-15Zr alloy, Tc appears to distribute between the intermetallic phase (30\%) and the iron phases (70\%) (Frank et al. 2007). Waste loading of $2 \mathrm{wt} \%$ Tc has been demonstrated but much higher waste loadings to 10 to $20 \mathrm{wt} \%$ Tc are believed possible based on experimental work with Re (Frank et al. 2007).

Studies are underway to understand the corrosion behavior and contaminant release from the metal alloy waste forms (Ebert and Kolman 2013). A uniform aqueous corrosion rate model has been used to describe the corrosion rate, and a linear-polarization electrochemical method has been used to determine the corrosion rate. The corrosion rate has been estimated to be approximately $0.027 \mathrm{~g} / \mathrm{m}^{2} \mathrm{~d}$ in the Yucca Mountain environment (Frank et al. 2007). The measured Tc release rate was $0.0023 \mathrm{~g} / \mathrm{m}^{2} \mathrm{~d}$. Ebert (2005) describes the extensive testing conducted to evaluate the suitability of the stainless steel/Zr alloy as a waste form for disposal at the then-planned Yucca Mountain repository.

Long-term alloy corrosion studies have continued and a conceptual model has been developed for metal alloy waste form degradation (Ebert 2013). The conceptual model involves a two-step process. First, the metal alloy and radionuclides must be oxidized by electrochemical and chemical processes through contact with the contacting solution. Second, the oxidized materials must be dissolved into the contacting solution. The dissolution process depends on the specific oxide and may occur immediately or 
over some length of time. The electrochemical behavior is modeled based on the electrochemical theory of mixed potential and electrode kinetics (Ebert 2013). Standard electrochemical techniques are used with some modifications to study the chemical effects in parallel with the electrochemical effects. Surface analysis techniques are needed to help interpret the electrochemical results, and other experiments are needed to understand the effects of passivating layers that form during the waste form corrosion.

Most recently, the work with iron-based alloys has moved to Fe-Mo metallic waste forms for the combined waste streams including undissolved solids, separated Tc and the raffinate from the TRansUranium EXtraction (TRUEX) process (Ebert et al. 2009, Ebert et al. 2010, Buck and Neiner 2010). Alloys with 43Fe-16Zr-15Mo and 47SS-7Zr-22Mo have been studied for waste streams with undissolved solids and recovered Tc. The Mo comes from the undissolved solids and the $\mathrm{Zr}$ comes from undissolved solids that are separated from TRUEX raffinate, hulls, or chemical additions.

Kolman et al. (2012) studied the corrosion of simple technetium-iron alloys with Tc concentrations at $0,10,50,90$, and $100 \mathrm{wt} \% \mathrm{Tc}$. Corrosion rates were derived from linear-polarization resistance measurements in $1 \times 10^{-4} \mathrm{M} \mathrm{H}_{2} \mathrm{SO}_{4}$ solution. Corrosion rates were significantly lower with $\mathrm{Tc}$ concentrations at 50\% and higher. The minimum corrosion rate was observed at 50\% Tc. The Fe corroded at a faster rate than the Tc.

\subsection{Tc Oxides}

Researchers at the University of Nevada, Las Vegas are conducting experimental work to develop waste forms consisting of ternary oxides of different structures that incorporate Tc within the structure (INL 2013). Structures currently under investigation are pyrochlore $\left(\operatorname{Ln}_{2} \mathrm{Tc}_{2} \mathrm{O}_{7}\right.$, where $\mathrm{Ln}=$ lanthanides), perovskite $\left(\mathrm{SrTcO}_{3}\right)$, and layered perovskite $\left(\mathrm{Sr}_{2} \mathrm{TcO}_{4}\right)$. These ceramic ${ }^{99} \mathrm{Tc}$-bearing waste forms synthesized to date exhibited good crystallinity. The lattice parameters and crystal structures of the Tc host phases have been measured with high accuracies.

Research conducted to date demonstrates that synthesis of pyrochlore $\left(\operatorname{Ln}_{2} \mathrm{Tc}_{2} \mathrm{O}_{7}\right)$, perovskite $\left(\mathrm{SrTcO}_{3}\right)$, and layered perovskite $\left(\mathrm{Sr}_{2} \mathrm{TcO}_{4}\right)$ can be accomplished successfully by applying a synthesis route that is fairly simple and is capable of being scaled up. This technique offers the opportunity to stabilize and immobilize several major fission products, $\mathrm{TcO}_{2}$ and $\mathrm{Ln}_{2} \mathrm{O}_{3}$ and/or $\mathrm{SrO}$, by incorporating them within ceramic crystalline structures, which are expected to be highly durable ${ }^{99} \mathrm{Tc}$ host phases and suitable waste forms to isolate ${ }^{99} \mathrm{Tc}$ from the environment. The researchers anticipate good radiation tolerance and good chemical stability under conditions of a generic geological repository. Testing the waste forms for chemical durability is ongoing using the PCT and ASTM C1220, static leaching of monolithic waste forms (ASTM 2010).

\subsection{Silicates}

Framework aluminosilicate minerals such as zeolites are known to incorporate ionic contaminants including radionuclides within their structure (Mattigod et al. 2006). Zeolites have been viewed as stable waste forms for contaminants because of their favorable properties, such as very low solubility and significant phase stability. For example, the zeolite mineral hydroxysodalite has been shown to entrap sodium salts, heavy metals, and radionuclides from reprocessing wastes at INL (Grutzeck and Siemer 1997). Also, glass-bonded salt-occluded sodalites prepared as stable ceramic forms for immobilizing rare 
earth and actinide elements such as cerium, uranium, and plutonium have been reported (Morss et al. 2000; Richman et al. 2001).

The cage-like structure of sodalite can trap and immobilize up to $9 \mathrm{~mol} \%$ of oxyanions. Several studies of oxyanion-containing sodalities have been conducted (Hund 1984; Srdanov et al. 1994; Buhl and Lons 1996; Fechtelkord 2000; Johnson et al. 2000; Buhl et al. 2001; Brenchley and Weller 1994).

Mattigod et al. (2006) have synthesized and characterized perrhenate (as an analog of pertechnetate) containing sodalite and determined its crystal structure. In this work, a sodalite was synthesized that contained $\mathrm{ReO}_{4}{ }^{-}$ions enclathrated in the $\mathrm{b}$ cages of the structure. It was suggested that pertechnetate sodalite could also be synthesized because Tc(VII) has an ionic radius that is only $2 \%$ smaller than that of $\operatorname{Re}(\mathrm{VII})$.

Um et al. (2005) studied radionuclide immobilization during secondary mineral formation during contact of simulated caustic wastes with sediments and minerals. Nitrate-cancrinite was the dominant secondary precipitate to form on mineral surfaces. Adsorption of ${ }^{99} \mathrm{Tc}(\mathrm{VII})$ onto nitrate-cancrinite was found to be significant but not great, with a distribution coefficient $\left(\mathrm{K}_{\mathrm{d}}\right)$ of $1.81 \mathrm{~mL} / \mathrm{g}$ (at $\mathrm{pH} 7.8$ ).

\subsection{Titanates}

$\mathrm{Tc}^{4+}$ has an ionic radius $\left(0.0645 \mathrm{~nm}\right.$, Shannon 1976) that is similar to that of $\mathrm{Ti}^{4+}(0.0605 \mathrm{~nm}$, Shannon 1976). As a result, $\mathrm{Tc}^{4+}$ can partially substitute for $\mathrm{Ti}^{4+}$ in titanate ceramics (Carter et al. 2007). Synthesis of the Tc-doped titanate ceramic Synroc has been reported (Hart et al. 1996; Vance et al. 1997, 1998). These waste forms contain $2-3 \mathrm{wt} \% \mathrm{Tc}$ in the form of metallic alloy and oxide phases such as perovskite, $\mathrm{Ca}(\mathrm{Ti}, \mathrm{Tc}) \mathrm{O}_{3}$, and rutile, $(\mathrm{Ti}, \mathrm{Tc}) \mathrm{O}_{2}$. Another host titanate phase suggested for $\mathrm{Tc}$ immobilization is Mg-titanate spinel, $\mathrm{Mg}_{2}(\mathrm{Ti}, \mathrm{Tc}) \mathrm{O}_{4}$ (Muller et al. 1964, Exter et al. 2006, Khalil and White 1983). Some chemical properties of Tc are similar to those of Mn, allowing the synthesis of Tc-Mn-bearing durable crystalline phases. In this case, Mn provides full Tc coprecipitation from solution and supports Tc incorporation into the crystalline structure of the Mn-bearing host phase. Synthesis of Tc-doped ceramics based on ( $\mathrm{Mn}, \mathrm{Fe}, \mathrm{Tc}) \mathrm{O}_{\mathrm{x}}$ and $(\mathrm{Zr}, \mathrm{Mn}, \mathrm{Tc}) \mathrm{O}_{\mathrm{x}}$ have been reported (Korneyko et al. 2009). A challenging problem associated with immobilization of Tc within ceramic waste forms is the necessity to reduce $\mathrm{Tc}^{7+}$ to $\mathrm{Tc}^{4+}$ during precursor preparation and/or ceramic synthesis.

Korneyko et al. (2012) recently reported on results of a new sorbent, layered hydrazinium titanate, LHT-9 (Britvin et al. 2010, 2011) for reductive adsorption of Tc from aqueous solution and one-step synthesis of a ceramic matrix. LHT-9 has the general formula $\left(\mathrm{N}_{2} \mathrm{H}_{5}\right) 1 / 2 \mathrm{Ti}_{1.87} \mathrm{O}_{4} x \mathrm{H}_{2} \mathrm{O}$ and it contains 6-7 $\mathrm{wt} \%$ of hydrazine chemically incorporated into the $\mathrm{TiO}_{2}$-based matrix (Britvin et al. 2010). This nonselective absorbent is able to take up more than 50 elements (Britvin et al. 2011). It was demonstrated that LHT $-9(5 \mathrm{~g} / \mathrm{L})$ could reductively adsorb up to $90.2 \%$ of Tc from aqueous solutions containing $0.5 \mathrm{~g} \mathrm{Tc} / \mathrm{L}$. The adsorption products are easily converted into a stable titanate ceramic by one-step sintering in argon at $1200^{\circ} \mathrm{C}$.

Tang et al. (2013) reported on the effect of irradiation on $\mathrm{Sr}_{n+1} \mathrm{Ti}_{n} \mathrm{O}_{3 n+1}$ Ruddlesden-Popper phases synthesized by hot forging. Radiation damage effects in the Ruddlesden-Popper phases $\operatorname{Sr}_{n+1} \operatorname{Ti}_{n} \mathrm{O}_{3 n+1}$ with $\mathrm{n}=2$ and $\infty$ obtained by a hot-forging route has been investigated using $200 \mathrm{keV} \mathrm{He}$ ion irradiation at room temperature. Grazing-incidence XRD measurements and transmission electron microscopy observations on both $\mathrm{SrTiO}_{3}$ and $\mathrm{Sr}_{3} \mathrm{Ti}_{2} \mathrm{O}_{7}$ compounds reveal three ion irradiation-induced phenomena: 
first, a volume swelling effect after irradiation was observed in both compounds; second, initially microsized grains were refined into nano-sized grains during irradiation; third, amorphization was observed in irradiated $\mathrm{Sr}_{3} \mathrm{Ti}_{2} \mathrm{O}_{7}$, while no amorphous phase was observed in irradiated $\mathrm{SrTiO}_{3}$. The authors note that the highest known reported dose for perovskite without amorphization is $5 \mathrm{dpa}^{4}$

Although the studies cited above demonstrate the feasibility of incorporating Tc into various titanate phases, to our knowledge, no studies of the leachability of these sequestering agents have been reported. Leaching studies of both the titanate sequestering agents as well as the agents incorporated within a final waste form would be needed to assess the effectiveness of these titanate phases for immobilizing Tc.

\subsection{Sulfides}

Technetium in the reduced Tc(IV) oxidation state forms compounds that have relatively low solubility compared to Tc(VII), which forms compounds that are generally very soluble. For example, the Tc concentrations in equilibrium with $\mathrm{TcO}_{2} \bullet x \mathrm{H}_{2} \mathrm{O}$ over the $\mathrm{pH}$ range of 4-10 range from approximately $10^{-8}$ to $2.4 \times 10^{-10} \mathrm{M}$ (Icenhower et al. 2010). The solubilities of Tc(IV) sulfides are even lower. Using data from Rard (1983), O'Kelly (1987) calculated that the Tc concentration in equilibrium with $\mathrm{TcS}_{2}$ at $\mathrm{pH} 12$ was approximately $10^{-30} \mathrm{M}$. Equilibrium Tc concentrations below $\mathrm{pH} 12$ were even lower for this sulfide compound.

Saltstone is a cementitious waste form developed to immobilize contaminants from low-level liquid waste (Kaplan et al. 2008), (see Section 4.2 above). This engineered waste form is produced by mixing liquid waste with cement, fly ash, and BFS. The BFS acts as a reducing agent and contains sulfur concentrations that typically range from 1.0 to $1.9 \%$ (Federal Highway Administration 2012). Lukens et al. (2005) reported that two reduced Tc solid phases, $\mathrm{TcO}_{2} \cdot 2 \mathrm{H}_{2} \mathrm{O}$ and $\mathrm{TcS}_{\mathrm{x}}$ occur in Saltstone. More recently, Um et al. (2011b) used XANES to determine the speciation of Tc in a number of samples of Cast Stone, which is a cementitious waste form containing BFS and is similar to Saltstone. They determined that the Tc phases $\mathrm{TcO}_{2} \cdot 2 \mathrm{H}_{2} \mathrm{O}$ and $\mathrm{Tc}_{2} \mathrm{~S}_{7}$ were present in their samples. Cantrell and Williams (2013) demonstrated that Tc release from Saltstone under anoxic conditions is likely controlled by the solubility of the reduced oxide phase $\mathrm{TcO}_{2} \bullet x \mathrm{H}_{2} \mathrm{O}$, even if $\mathrm{TcS}_{\mathrm{x}}$ phases are present because of the higher solubility of the oxide phases.

Because Tc sulfide phases exhibit very low solubility, these phases are potentially attractive as sequestering agents for Tc. A significant limitation for their use in waste forms is the fact that these phases readily oxidize in the presence of oxygen and possibly other oxidants (Burke et al. 2006). As a result, successful application of Tc sulfides for immobilization of Tc would require that these materials be disposed in a reducing environment or within a waste form that greatly limits exposure to oxygen or other potential oxidants.

\subsection{Phosphates (Apatites)}

Thomson et al. (2003) studied the use of natural and synthetic apatites, tricalcium phosphate, bone char, and activated magnetite for removal of a number of radionuclides including Tc from wastewater.

\footnotetext{
${ }^{4} \mathrm{dpa}=$ displacements per atom
} 
Their results indicated that removal of uranium and plutonium by the phosphate absorbents was very good, but only moderate sorption was observed for Tc.

\subsection{Layered Double Hydroxides}

Layered double hydroxides are a type of material that is capable of capturing anions such as $\mathrm{TcO}_{4}{ }^{-}$ within the LDH structure (Phillips and Vandeperre 2010). LDHs are composed of metal hydroxide sheets with hydrated anions between the sheets to balance the positive charge of the metal hydroxides. The LDHs have the general formula $\left[\mathrm{M}_{(1-\mathrm{II})}^{\mathrm{II}} \mathrm{M}_{(\mathrm{x})}^{\mathrm{III}}(\mathrm{OH})_{2}\right]^{\mathrm{x+}}$ where $\mathrm{M}^{\mathrm{II}}$ and $\mathrm{M}^{\mathrm{III}}$ are divalent and trivalent cations.

A magnesium/aluminum LDH known as hydrotalcite $\left[\mathrm{Mg}_{6} \mathrm{Al}_{2}(\mathrm{OH})_{16} \mathrm{CO}_{3} \cdot 4 \mathrm{H}_{2} \mathrm{O}\right]$ has been evaluated as a separations medium for ${ }^{99 \mathrm{~m}} \mathrm{Tc}$ for medical isotope applications (Serrano et al. 2005, Dash et al. 2013). As a ${ }^{99 \mathrm{~m}} \mathrm{Tc}$ generator, ${ }^{99} \mathrm{MoO}_{4}{ }^{2-}$ is loaded onto the hydrotalcite. Both $\mathrm{TcO}_{4}{ }^{-}$and $\mathrm{MoO}_{4}{ }^{2-}$ anions are retained on the hydrotalcite. Because the hydrotalcite has a greater affinity for the divalent anion than the monovalent anion, the $\mathrm{TcO}_{4}{ }^{-}$can then be selectively eluted using a $0.1 \mathrm{M} \mathrm{NaCl}$ solution or a $0.1 \mathrm{M} \mathrm{HNO}_{3}$ solution.

Kang et al. $(1996,1999)$ investigated the sorption of $\mathrm{TcO}_{4}{ }^{-}$and $\mathrm{ReO}_{4}{ }^{-}$anions on a $\mathrm{Mg} / \mathrm{Al} \mathrm{LDH}$ for potential application to remove Tc from radioactive wastewaters. They determined that the sorption is through an ion exchange process

$$
\mathrm{Mg}_{6} \mathrm{Al}_{2}(\mathrm{OH})_{18}(\mathrm{~s})+\mathrm{MO}_{4}^{-} \leftrightarrow \mathrm{Mg}_{6} \mathrm{Al}_{2}(\mathrm{OH})_{17}\left(\mathrm{MO}_{4}\right)(\mathrm{s})+\mathrm{OH}^{-}
$$

with an equilibrium constant of $1.40 \pm 0.11$. Their experiments were conducted under conditions that would exclude carbonate, which can compete for the anion exchange sites in the LDH. They recommend that the influence of other anions in expected wastewater solutions be investigated.

Of particular interest is the CaAlFe LDH system. When heat treated, this LDH forms a ferrite phase, $\mathrm{Ca}_{2}\left(\mathrm{Al}_{\mathrm{x}}, \mathrm{Fe}_{(1-\mathrm{x})}\right)_{2} \mathrm{O}_{5}$, which is one of the phases in ordinary Portland cement (Taylor 1997). Conceptually, this material could be incorporated into a cementitious waste form to immobilize the $\mathrm{TcO}_{4}{ }^{-}$anion. Phillips and Vandeperre (2010) prepared an $\mathrm{LDH}$ with the nominal composition $\mathrm{Ca}_{0.67}\left(\mathrm{Al}_{0.5}, \mathrm{Fe}_{0.5}\right)_{0.33}$ $(\mathrm{OH})_{2} 0.33\left(\mathrm{NO}_{3}\right) \cdot x \mathrm{H}_{2} \mathrm{O}$. They examined the ability of this material to capture anions including carbonate, chloride, nitrate, and perrhenate. They observed that the anions preferentially intercalate into the $\mathrm{LDH}$ phases in the order $\mathrm{Cl}^{-}>\mathrm{CO}_{3}{ }^{2-}>\mathrm{NO}_{3}{ }^{-}>\mathrm{ReO}_{4}{ }^{-}$. The uptake of the perrhenate into the $\mathrm{LDH}$ structure was lower than expected. Because most liquid waste streams produced at the Hanford Site, especially those destined to be processed through the WTP, contain several molar concentrations of nitrate and nitrite and greater than millimolar concentrations of carbonate and chloride, these anions would strongly compete with $\mathrm{TcO}_{4}{ }^{-}$and likely preclude $\mathrm{Tc}$ incorporation into the $\mathrm{LDH}$ metal oxide interlayers.

\subsection{Sulfur-Based Aerogels}

Aerogels are highly porous semisolids. When prepared with non-oxide chalogens (sulfur, selenium, tellurium), heavy metals have a tendency to bind to the "chalcogels," suggesting a potential for environmental remediation applications (Riley et al. 2013). Chalcogels can be prepared by forming 
chemical linkages of chalcogen-containing clusters (Ge-S, Ge-Se, Sn-S, Sn-Se, Mo-S, W-S, and Fe-S) using selected metal ions $\left(\mathrm{Bi}^{3+}, \mathrm{Co}^{2+}, \mathrm{Ni}^{2+}, \mathrm{Sb}^{3+}, \mathrm{Sn}^{2+}\right.$, and $\mathrm{Zn}^{2+}$ ). Riley et al. (2013) investigated the use of five chalcogels for removal of uranium and technetium from solution and iodine from air. The chalcogels were effective for all three species. Table 5.3 shows the uptake of Tc from a $1 \times 10^{-6} \mathrm{M}$ $\mathrm{NaTcO}_{4}$ solution in deionized water. Further uptake tests using the highly saline, caustic wastes of interest would need to be performed to see whether sulfur-based aerogels have any utility for removal of $\mathrm{TcO}_{4}{ }^{-}$from WTP-relevant liquid waste streams. In addition, there was no mention of how stable the sulfur-based aerogels would be in the oxidizing subsurface IDF disposal environment. Additional work is needed to determine whether these aerogels can be converted to a stable waste form for Tc.

Table 5.3. Technetium Uptake by Sulfur-Based Aerogels (Riley et al. 2013)

\begin{tabular}{lcc}
\hline Chalcogel & $\begin{array}{l}\text { Capture } \\
\text { Efficiency } \\
\text { (percent) }\end{array}$ & $\begin{array}{l}\text { Distribution } \\
\text { Coefficient }\left(\mathbf{K}_{\mathbf{d}}\right) \\
(\mathbf{m L} / \mathbf{g})\end{array}$ \\
\hline CoBiMoS & 94.0 & $1.68 \times 10^{3}$ \\
CoCrMoS & 57.3 & $2.88 \times 10^{2}$ \\
CoNiMoS & 62.2 & $1.62 \times 10^{2}$ \\
PtGeS & 98.0 & $3.61 \times 10^{4}$ \\
SnS & 87.3 & $1.49 \times 10^{3}$ \\
\hline
\end{tabular}





\subsection{Conclusions}

Technetium-99 in the Hanford tank wastes is a particularly challenging radionuclide to disposition because of its volatility in the high-temperature vitrification processes planned for the HLW and LAW fractions of the tank wastes and because of its long half-life and the potential environmental impacts of disposing of the ${ }^{99} \mathrm{Tc}$ at the IDF. Consideration is being given to separating Tc from the LAW either before it is fed to the LAW glass melters or after the vitrification process from the off-gas scrubber solutions. Given those options, this literature survey identifies options for immobilization of the separated Tc. For the purposes of discussion, the options are divided into two categories. The first category includes waste forms for solidification of multiple components in a waste stream. Included are borosilicate and iron phosphate glasses, cementitious grouts, geopolymers, phosphate-bonded ceramics, the FBSR-generated aluminosilicate waste form, and the crystalline ceramic Synroc waste form. The second category includes waste forms specifically designed to immobilize Tc. Included are irontechnetium oxides, metal alloys, technetium oxides, silicate minerals, titanates, sulfides, phosphates, $\mathrm{LDH}$, and sulfur-based aerogels.

Within the first category, borosilicate glass and cementitious grouts are the most well-characterized of the waste forms. Borosilicate glass is used almost universally for the immobilization of HLW, with phosphate glass used in Russia and Synroc proposed for use on Australia's intermediate level waste. Although the glass waste forms are effective in immobilizing Tc, the high temperatures of the glass melting processes result in extra processing measures to increase the retention of Tc in the glass. Efforts are underway to improve the retention of Tc during the vitrification process. Grouts are low-temperature waste forms that do not have the volatility challenges of the glass waste forms but may not be as effective in controlling the release of Tc in the disposal environment. Work is in progress to improve the retention of Tc in the grouts by way of "getters" to reduce and control the oxidation state of the Tc and/or by the addition of fillers to effectively slow the diffusion path by which the Tc is released from grout waste forms.

Within the second category, stainless steel metal alloys are the most well-characterized of the Tc-specific waste forms. Work has been conducted at scales from laboratory and benchtop to full-scale process demonstrations. Extensive work has been done on the corrosion rates and mechanisms for the metal alloys, and waste form qualification strategies have been developed. For the other Tc-specific waste forms, the development efforts are at the laboratory scale and are at various stages of waste form characterization and leaching studies. It is noted that some of the Tc-specific waste forms may be more mature because of their inclusion in some of the multiphase/multi-waste-component waste forms. For example, sodalite is a component of the FBSR product and pyrochemical salt waste forms and some of the titanate forms are components of Synroc. Table 6.1 shows some of the advantages and disadvantages associated with the Tc-specific waste forms. 
Table 6.1. Comparison of Advantages and Disadvantages of Tc-Specific Waste Forms

\begin{tabular}{|c|c|}
\hline Advantages & Disadvantages \\
\hline \multicolumn{2}{|c|}{ Iron-technetium oxides } \\
\hline $\begin{array}{l}\text { - Iron oxyhydroxides relatively stable in } \\
\text { subsurface oxic environments } \\
\text { - } \quad \text { Forms stable crystal structure with Tc } \\
\text { - } \quad \text { Potential to add protective coating to } \\
\text { further isolate Tc } \\
\text { - } \quad \text { Low-temperature process } \\
\end{array}$ & $\begin{array}{l}\text { - Other anions compete with Tc } \\
\text { - Relatively immature waste form } \\
\text { - Product is a granular material that } \\
\text { requires encapsulation to form the final } \\
\text { waste form }\end{array}$ \\
\hline \multicolumn{2}{|c|}{ Epsilon metal alloy } \\
\hline $\begin{array}{l}\text { - Low-volume waste form } \\
\text { - Natural analogs show essentially no } \\
\text { migration of Tc for millions of years } \\
\text { - Work has been done to create and } \\
\text { characterize epsilon metal alloy as a } \\
\text { waste form } \\
\text { - Volatility of Tc at high temperatures not } \\
\text { an issue for Tc metal }\end{array}$ & $\begin{array}{l}\text { - Requires expensive and precious metal to } \\
\text { form the alloy } \\
\text { - High-temperature melting process } \\
\text { - Requires reduction of Tc to the metal }\end{array}$ \\
\hline \multicolumn{2}{|c|}{ Stainless-steel-based alloys } \\
\hline $\begin{array}{l}\text { - Low-volume waste form } \\
\text { - Extensive characterization of stainless } \\
\text { steel alloys as a waste form } \\
\text { - Volatility of Tc at high temperatures not } \\
\text { an issue for Tc metal }\end{array}$ & $\begin{array}{l}\text { - High-temperature melting process } \\
\text { - } \quad \text { Requires reduction of Tc to the metal }\end{array}$ \\
\hline \multicolumn{2}{|c|}{ Tc oxides } \\
\hline - $\quad$ Crystalline waste form & - Relatively immature waste form \\
\hline \multicolumn{2}{|c|}{ Silicates } \\
\hline - $\quad$ Crystalline waste form & - Relatively immature waste form \\
\hline \multicolumn{2}{|c|}{ Titanates } \\
\hline $\begin{array}{l}\text { Form crystalline ceramic structure with } \\
\text { Tc(IV) }\end{array}$ & $\begin{array}{l}\text { - Require high-temperature sintering in an } \\
\text { inert atmosphere. } \\
\text { - No information available regarding } \\
\text { effectiveness of the Tc titanate minerals } \\
\text { in controlling the release of the Tc in } \\
\text { leaching }\end{array}$ \\
\hline \multicolumn{2}{|c|}{ Sulfides } \\
\hline $\begin{array}{ll}\text { - } & \text { Tc sulfide species have very low } \\
& \text { solubility } \\
\text { - } & \text { Reduce Tc oxides to } \mathrm{TcS}_{2} \\
\text { - } & \text { Basis for effective immobilization of Tc } \\
\text { in grout waste forms with BFS }\end{array}$ & $\begin{array}{l}\text { Readily oxidize in presence of oxygen to } \\
\text { form soluble species with high mobility } \\
\text { - Path to forming a waste form for disposal } \\
\text { is undefined }\end{array}$ \\
\hline
\end{tabular}


Table 6.1 (cont)

\begin{tabular}{|c|c|}
\hline Advantages & Disadvantages \\
\hline \multicolumn{2}{|c|}{ Phosphates (apatites) } \\
\hline $\begin{array}{l}\text { Apatites being evaluated as means to } \\
\text { enhance retention of Tc in Cast Stone } \\
\text { waste form }\end{array}$ & $\begin{array}{l}\text { - Relatively immature technology as a } \\
\text { waste form } \\
\text { - } \quad \text { Effectiveness in removing Tc from waste } \\
\text { streams remains to be demonstrated } \\
\text { - Path to forming a waste form for disposal } \\
\text { is undefined. }\end{array}$ \\
\hline \multicolumn{2}{|c|}{ Layered double hydroxides } \\
\hline $\begin{array}{l}\text { Developed as a separations technology } \\
\text { for medical isotope industry and for } \\
\text { contaminated wastewater treatment }\end{array}$ & $\begin{array}{l}\text { - Relatively immature technology as a } \\
\text { waste form } \\
\text { - } \mathrm{LDH} \text { would likely need to be } \\
\text { encapsulated in another waste form } \\
\text { - Other anions in waste will compete with } \\
\mathrm{TcO}_{4}^{-} \text {and will likely preclude Tc } \\
\text { incorporation into LDH }\end{array}$ \\
\hline \multicolumn{2}{|c|}{ Sulfur-based aerogels } \\
\hline $\begin{array}{l}\text { Being developed for environmental } \\
\text { remediation applications }\end{array}$ & $\begin{array}{l}\text { Testing needed to evaluate efficacy for } \\
\text { caustic tank waste applications } \\
\text { - Path to forming a waste form for disposal } \\
\text { is undefined } \\
\text { - Resistance to oxidation in the disposal } \\
\text { environment is unknown }\end{array}$ \\
\hline
\end{tabular}





\subsection{References}

40 CFR 268. Code of Federal Regulations, Title 40, Protection of Environment, Part 268, "Land Disposal Restrictions."

Abraham DP, SM McDeavitt, and J Park. 1996. "Microstructure and Phase Identification in Type 304 Stainless Steel-Zirconium Alloys.” Metallurgical and Materials Transactions 27A (1996) 2151.

Abramowitz H, M Brandys, R Cecil, N D’Angelo, KS Matlack, IS Muller, IL Pegg, and RA Callow. 2012. Technetium Retention in WTP LAW Glass with Recycle Flow-Sheet: DM10 Melter Testing. RPP-54130, Rev. 0, Washington River Protection Solutions LLC, Richland, WA.

Allen PG, GS Siemering, DK Shuh, JJ Bucher, NM Edelstein, CA Langton, SB Clark, T Reich, and MA Denecke. 1997. "Technetium Speciation in Cement Waste Forms Determined by XANES." Radiochimica Acta 76:77-86.

ANSI/ANS-16.1-2003;R2008 (R=Reaffirmed): Measurement of the Leachability of Solidified Low-Level Radioactive Wastes by a Short-Term Test Procedure. American Nuclear Society, Washington, D.C.

ASTM C1220 - 10. 2010. Standard Test Method for Static Leaching of Monolithic Waste Forms for Disposal of Radioactive Waste. ASTM International, West Conshohocken, PA.

ASTM C1285. 2008a. Standard Test Methods for Determining Chemical Durability of Nuclear, Hazardous, and Mixed Waste Glasses and Multiphase Glass Ceramics: The Product Consistency Test (PCT). ASTM International, West Conshohocken, PA.

ASTM C1308. 2008b. Standard Test Method for Accelerated Leach Test for Diffusive Releases from Solidified Waste and a Computer Program to Model Diffusive, Fractional Leaching from Cylindrical Waste Forms. ASTM International, West Conshohocken, PA.

Barkatt A, BC Gibson, PB Macedo, CJ Montrose, W Sousanpour, A Barkatt, MA Boroomand, V Rogers, and M Penafiel. 1986. "Mechanisms of Defense Waste Glass Dissolution.” Nuclear Technology 73:140-164.

Bonnesen PV, BA Moyer, DJ Presley, VS Armstrong, TJ Haverlock, RM Counce, and RA Sachleben. 1996. Alkaline-Side Extraction of Technetium From Tank Waste Using Crown Ethers and Other Extractants. ORNL/TM-13241, Oak Ridge National Laboratory, Oak Ridge, TN.

Bourcier WL. 1991. “Overview of Chemical Modeling of Nuclear Waste Glass Dissolution.” Material Research Symposium Proceedings 212:3-17.

Brenchley ME and MT Weller. 1994. "Synthesis and structures of $\mathrm{M}_{8}\left[\mathrm{ALSiO}_{4}\right]_{6} \cdot\left(\mathrm{XO}_{4}\right)_{2}, \mathrm{M}=\mathrm{Na}, \mathrm{Li}, \mathrm{K}$; $\mathrm{X}=\mathrm{Cl}$, Mn Sodalites.” Zeolites 14(8):682.

Britvin SN, W Depmeier, SV Krivovichev, OI Siidra, AA Zolotarev, VV Gurzhiy, DV Spiridonova. 2010 PCT Pat. Appl. PCT/EP2010/001864. 
Britvin SN, A Lotnyk, L Kienle, SV Krivovichev, and W Depmeier. 2011. J. Am. Chem. Soc., 133(24):9516-9525.

Buck EC and D Neiner. 2010. Electron Microscopy Characterization of Tc-Bearing Metallic Waste Forms - Final Report FY10. PNNL-19837, Pacific Northwest National Laboratory, Richland, WA.

Buhl JC and J Lons. 1996. Synthesis and crystal structure of nitrate enclathrated sodalite $\mathrm{Na}_{8}\left[\mathrm{AlSiO}_{4}\right]_{6}\left(\mathrm{NO}_{3}\right)_{2}$. J. Alloys Comp. 235:41-47.

Buhl JC, TM Gesing, and C Gurris. 2001. Synthesis and crystal structure of rhodanide-enclathrated sodalite $\mathrm{Na}_{8}\left[\mathrm{AlSiO}_{4}\right]_{6}(\mathrm{SCN})_{2}$. Micropor. Mesopor. Mater. 50:25-32.

Bunker BC, DR Tallant, TJ Headley, GL Turner, and RJ Kirkpatrick. 1988. “The Structure of Leached Sodium Borosilicate Glass.” Physics and Chemistry of Glasses 29(3):106-120.

Burakov BE, MI Ojovan, and WE Lee. 2010. Crystalline Materials for Actinide Immobilisation. Imperial College Press, London, 198 pp. http://www.icpress.co.uk/engineering/p652.html.

Burbank DA. 2005. Waste Acceptance Criteria for the Immobilized Low-Activity Waste Disposal Facility. RPP-8402 Rev. 1, CH2M HILL Hanford Group, Inc., Richland, WA.

Burgeson IE, JR Deschane, and DL Blanchard Jr. 2005. "Removal of Technetium from Hanford Tank Waste Supernates." Separation Science and Technology 40:1-3, 201-223. DOI: 10.1081/SS-200041916.

Burke DB, C Boothman, JR Lloyd, FR Livens, JM Charnock, JM McBeth, RJG Mortimer, and K Morris. 2006. "Reoxidation Behavior of Technetium, Iron, and Sulfur in Estuarine Sediments." Environmental Science and Technology 40: 3529-3535. doi: 10.1021/es052184t.

Cantrell KJ and JH Westsik, Jr. 2011. Secondary Waste Form Down Selection Data Package -- Ceramicrete. PNNL-20681, Pacific Northwest National Laboratory, Richland, WA.

Cantrell KJ and BD Williams. 2013. "Solubility Control of Technetium Release from Saltstone by $\mathrm{TcO}_{2} \cdot \mathrm{xH}_{2} \mathrm{O}$.” Journal of Nuclear Materials 437(1-3):424-431.

Carter ML, MWA Stewart, ER Vance, BD Begg, S Moricca, and J Tripp. 2007. "HIPed Tailored Ceramic Waste Forms for the Immobilization of $\mathrm{Cs}$, Sr and Tc." Proceedings of the Advanced Nuclear Fuel Cycles and Systems (GLOBAL '07, Boise, ID). INL/CON-07-12875, Idaho National Laboratory, Idaho Falls, ID, USA, pp. 1022-1028.

Casey WH and BC Bunker. 1990. "Leaching of Mineral and Glass Surfaces During Dissolution." Mineral-Water Interface Geochemistry. MF Hochella, Jr. and AF White (eds.), Mineralogical Society of America 23:397-426.

Crum JV, D Strachan, A Rohatgi, and M Zumhoff. 2013. "Epsilon metal waste form for immobilization of noble metals from used nuclear fuel.” Journal of Nuclear Materials, 441:103-112.

Cui D, T Eriksen, and U-B Eklund. 2001. “On Metal Aggregates in Spent Fuel, Synthesis and Leaching of Mo-Ru-Pd-Rh Alloy." Materials Research Society Symposium Proceedings 663:427-34. 
Cunnane JC, JK Bates, and CR Bradley. 1994a. High-level Borosilicate Waste Glass: A Compendium of Corrosion Characteristics, Vol. 1. DOE-EM-0177, U.S. Department of Energy, Office of Waste Management, Springfield, VA.

Cunnane JC, JK Bates, and CR Bradley. 1994b. High-Level Waste Borosilicate Glass: A Compendium of Corrosion Characteristics, Vol. 2. DOE-EM-0177, U.S. Department of Energy, Office of Waste Management, Springfield, VA.

Darab JG and PA Smith. 1996. Chemistry of Technetium and Rhenium during Low-Level Radioactive Waste Vitrification." Chem. Mater. Vol 8 No. 5 1004-1021.

Dash A, FF Knapp, Jr., and MRA Pillai. 2013. “99Mo/99mTc separation: An assessment of technology options." Nuclear Medicine and Biology 40:167-176.

Day DE, RK Brow, CS Ray, C Kim, ST Reis, JD Vienna, D Peeler, FC Johnson, EK Hansen, G Sevigny, N Solberg, IL Pegg, and H Gan. 2012. "Iron Phosphate Glass for Vitrifying Hanford AZ102 LAW in Joule Heated and Cold Crucible Induction Melters." In: WM2012: Improving the Future in Waste Management, February 26-March 1, 2012, Phoenix, AZ, USA. Paper no. 12240. WM Symposia, Tempe, AZ.

Duncan JB, SE Kelly, RA Robbins, RD Adams, MA Thorson, and CC Haass. 2011. Technetium Sorption Media Review. RPP-RPT-50122, Washington River Protection Solutions, Richland, WA.

Ebert WL. 2005. Testing to Evaluate the Suitability of Waste Forms for Electrometallurgically Treated Spent Sodium-Bonded Nuclear Fuel for Disposal in the Yucca Mountain Repository. ANL-05/43, Argonne National Laboratory, Argonne, IL.

Ebert W, M Williamson, and S Frank. 2009. Immobilizing Tc-Bearing Waste Streams in an Iron-Based Alloy Waste Form. AFCI-WAST-PMO-MI-DV-2009-000160, Argonne National Laboratory, Argonne, IL.

Ebert W, J Cunnane, M Williamson, S Frank, E Buck, D Kolman, E Mausolf, and D Shoesmith. 2010. FY2010 Status Report: Developing an Iron-Based Alloy Waste Form. AFCI-WAST-2010-000161, Argonne National Laboratory, Argonne, IL.

Ebert WL and D Kolman. 2013. Alloy Waste Form Testing Strategy Roadmap. FCRD-SWF-2013000226, Argonne National Laboratory, Argonne, IL.

Ebert WL. 2013. "Chapter 10: Waste Form Performance over Geologic Timescales." in Separations and Waste Forms Research and Development FY 2013 Accomplishments Report. INL/EXT-13-30961, Idaho National Laboratory, Idaho Falls, ID.

EPA. 1992. Toxicity Characteristic Leaching Procedure. EPA Method 1311, Revision 0, U.S. Environmental Protection Agency, Washington, D.C.

EPA. 2009. Mass Transfer Rates of Constituents in Monolith or Compacted Granular Materials Using a Semi-Dynamic Tank Leaching Test. EPA Draft Method 1315, U.S. Environmental Protection Agency, Washington, D.C. 
EPA. 2012a. Liquid-Solid Partitioning as a Function of Extract pH Using a Parallel Batch Extraction Procedure. EPA Method 1313, U.S. Environmental Protection Agency, Washington, D.C.

EPA. 2012b. Liquid-Solid Partitioning as a Function of Liquid-To-Solid Ratio in Solid Materials Using a Parallel Batch Procedure. EPA Method 1316, U.S. Environmental Protection Agency, Washington, D.C.

Exter MJ, S Neumann, and T Tomasberger. 2006. "Immobilization and Behavior of Technetium in a Magnesium Titanate Matrix for Final Disposal." Proc. Mat. Res. Soc. Symp. Scientific Basis for Nuclear Waste Management XXIX 932:567-574.

Fechtelkord M. 2000. Influence of Sodium Ion Dynamics on the ${ }^{23} \mathrm{Na}$ Quadrupolar Interaction in Sodalite: A High-Temperature ${ }^{23}$ Na MAS NMR Study. Solid State. Nucl. Mag. Res. 18:70.

Federal Highway Administration. 2012. User Guidelines for Waste and Byproduct Materials in Pavement Construction. FHWA-RD-97-148. Accessed July 2, 2012, at http://www.fhwa.dot.gov/publications/research/infrastructure/structures/97148/bfs1.cfm.

Frank SM, DD Keiser, Jr., and KC Marsden. 2007. Immobilization of Technetium in a Metallic Waste Form. INL/CON-07-12883, Idaho National Laboratory, Idaho Falls, ID.

Geckeis VMH, E González-Robles, A Loida, C Bube, and B Kienzler. 2012. "Radionuclide Behavior in the Near-field of a Geological Repository for Spent Nuclear Fuel.” Radiochimica Acta 100:699-713.

Grutzeck MW and DD Siemer. 1997. "Zeolites Synthesized from Class F Fly Ash and Sodium Aluminate Slurry." J. Am. Ceram. Soc. 80:2449.

Harbour JR and AS Aloy. 2007. International Program: Summary Report on the Properties of Cementitious Waste Forms. WSRC-STI-2007-00056, Revision 0, Savannah River National Laboratory, Aiken, SC.

Hart KP, ER Vance, RA Day, BD Begg, PJ Angel, and A Jostsons. 1996. "Immobilization of Separated Tc and Cs/Sr in Synroc.” Mat. Res. Soc. Symp. Proc. Scientific Basis for Nuclear Waste Management XIX 412:281-287.

Hassan NM, K Adu-Wusu, and CA Nash. 2004. Multiple Ion Exchange Column Runs for Cesium and Technetium Removal from AW-101 Waste Sample. WSRC-TR-2003-000098, Revision 1, Westinghouse Savannah River Company, Aiken, SC.

Hench LL, DE Clark, and AB Harker. 1986. "Nuclear Waste Solids.” Journal of Materials Science 21:1457-1478.

Hund FZ. 1984. "Nitrit-, Cyanid- und Rhodanid-Sodalith” Anorg. Allg. Chem. 511:225. (In German).

IAEA. 1977. Techniques for the Solidification of High-Level Wastes. International Atomic Energy Agency, Vienna, Austria. 
Icenhower JP, S Samson, A Luttge, and BP McGrail. 2004. "Towards a Consistent Rate Law: Glass Corrosion Kinetics Near Saturation." In Energy, Waste, and the Environment: A Geochemical Perspective, R Giere and P Stille (eds.), Geological Society of London 236:579-594.

Icenhower JP, N Qafoku, WJ Martin, and JM Zachara. 2008. The Geochemistry of Technetium: A Summary of the Behavior of an Artificial Element in the Natural Environment. PNNL-18139, Pacific Northwest National Laboratory, Richland, WA.

Icenhower JP, NP Qafoku, JM Zachara, DM Wellman, and WJ Martin. 2009. A Review of Tc Geochemistry: The Behavior of an Artificial Element in the Natural Environment. WM2009 Manuscript 9384, WM Symposia, Phoenix, AZ.

Icenhower JP, N Qafoku, JM Zachara, and WJ Martin. 2010. “The Biogeochemistry of Technetium: A review of the behavior of an artificial element in the natural environment." American Journal of Science Vol. 310(8):721-752. doi:10.2475/08.2010.02.

INL. 2013. Separations and Waste Forms Research and Development FY 2012 Accomplishments Report. FCRD-SWF-2013-000073, INL/EXT-12-27936, Revision 1, Idaho National Laboratory, Idaho Falls, ID.

Jantzen CM. 2002. Engineering Study of the Hanford Low Activity Waste (LAW) Steam Reforming Process (U). Savanah River National Laboratory, Aiken, SC.

Jantzen C, CL Crawford, P Burket, WE Daniel, AD Cozzi, and CJ Bannochie. 2011. Radioactive Demonstrations of Fluidized Bed Steam Reforming (FBSR) as a Supplemental Treatment for Hanford's Low-Activity Waste (LAW) and Secondary Wastes (SW). Waste Management 2011, Phoenix, AZ.

Jantzen CM, CL Crawford, CJ Bannochie, PR Burket, AD Cozzi, WE Daniel, HK Hall, DH Miller, DM Missimer, CA Nash, and MF Williams. 2013. Radioactive demonstration of mineralized waste forms made from Hanford Low Activity Waste (Tank Farm Blend) by Fluidized Bed Steam Reformation (FBSR). SRNL-STI-2011-00383, Savannah River National Laboratory, Aiken, SC.

Janzten CM, EM Pierce, CJ Bannochie, PR Burket, AD Cozzi, CL Crawford, WE Daniel, KM Fox, CC Herman, DH Miller, DM Missimer, CA Nash, MF Williams, CF Brown, NP Qafoku, JJ Neeway, MM Valenta, GA Gill, DJ Swanberg, RA Robbins, and LE Thompson. 2014. Fluidized Bed Steam Reformed Mineral Waste Form Performance Testing to Support Hanford Supplemental Low Activity Waste Immobilization Technology Selection. SRNL-STI-2011-00387, Rev. 0, Savannah River National Laboratory, Aiken, SC.

Jin T, D Kim, and MJ Schweiger, "Effect of Sulfate on Rhenium Partitioning during Melting of Low Activity-Waste Glass Feeds - 14116." Submitted to Proceedings of the WM2014 Conference, March 2-6, 2014, Phoenix, AZ.

Johnson GM, PJ Mead, and MT Weller. 2000. "Synthesis of a range of anion-containing gallium and germanium sodalites.” Micropor. Mesopor. Mater. 38:445.

Kang MJ, SW Rhee, H Moon, V Neck, and T Fanghanel. 1996. "Sorption of $\mathrm{MO}_{4}{ }^{-}(\mathrm{M}=\mathrm{Tc}, \mathrm{Re})$ on Mg/AL Layered Double Hydroxide by Anion Exchange.” Radiochimica Acta, 75:169-173. 
Kang MJ, KS Chun, SW Rhee, and Y Do. 1999. "Comparison of Sorption Behavior of I" and $\mathrm{TcO}_{4}$ " on Mg/AL Layered Double Hydroxide.” Radiochimica Acta 85:57-63.

Kaplan DI. 2003. Estimated Duration of the Subsurface Reducing Environment Produced by the Z-Area Saltstone Disposal Facility. WSRC-RP-2003-00362, Revision 1, Westinghouse Savannah River Company, Aiken, SC.

Kaplan DI, T Hang, and SE Aleman. 2005. Estimated Duration of the Reduction Capacity Within a High-Level Waste Tank (U). WSRC-RP-2005-01674, Revision 0, Westinghouse Savannah River Company, Aiken, SC.

Kaplan DI, KA Roberts, J Coates, M Siegfried, and S Serkiz. 2008. Saltstone and Concrete Interactions with Radionuclides: Sorption (Kd), Desorption, and Reduction Capacity Measurements.

SRNL-STI-2008-00045, Savannah River National Laboratory, Aiken, SC.

Khalil MY and WB White. 1983. "Magnesium Titanate Spinel: A Ceramic Phase for Immobilization of Technetium-99 from Radioactive Wastes." Commun. Amer. Ceram. Soc., 11:197-198.

Kim CW and DE Day. 2003. "Immobilization of Hanford LAW in iron phosphate glasses," Journal of Non-Crystalline Solids 331:20-31.

Kim DS, MJ Schweiger, WC Buchmiller, JD Vienna, DE Day, D Zhu, CW Kim, TE Day, T Neidt, DK Peeler, TB Edwards, IA Reamer, and RJ Workman. 2003a. Iron Phosphate Glass as An Alternative Waste-Form for Hanford LAW. PNNL-14251, Pacific Northwest National Laboratory, Richland, WA.

Kim D, JD Vienna, and P Hrma. 2003b. "Phosphate Glasses for Vitrification of Wastes with High Sulfur Content." In Environmental Issues and Waste Management Technologies VIII, Ceramic Transactions 143:337-345.

Kim CS, D Zhu, DE Day, D Kim, JD Vienna, DK Peeler, TE Day, and T Neidt. 2004. "Iron Phosphate Glass for Immobilization of Hanford LAW." In Environmental Issues and Waste Management Technologies IX, Ceramic Transactions, Vol. 155, 309-318.

Kim D, CZ Soderquist, JP Icenhower, BP McGrail, RD Scheele, BK McNamara, LM Bagaasen, MJ Schweiger, JV Crum, JD Yeager, J Matyáš, LP Darnell, HT Schaef, AT Owen, AE Kozelisky, LA Snow, and MJ Steele. 2005. Tc Reductant Chemistry and Crucible Melting Studies with Simulated Hanford Low-Activity Waste. PNNL-15131, Pacific Northwest National Laboratory, Richland, WA.

Kim DS and JD Vienna. 2012. Preliminary ILAW Formulation Algorithm Description. 24590-LAW-RPT-RT-04-0003, Rev. 1, River Protection Project, Hanford Tank Waste Treatment and Immobilization Plant, Richland, WA.

King WD and TB Calloway. 2000. Tank 241-AZ-102 SuperLig ${ }^{\circledR}$ 639Technetium Ion Exchange Eluate Evaporation Study. WSRC-TR-2000-00424, Westinghouse Savannah River Company, Aiken, SC.

Kolman DG, DP Moore, GD Jarvinen, GS Goff, X Chen, RR Gibson, MR Cisneros, CD Taylor, K Czersinski, and E Mausolf. 2012. The Aqueous Corrosion Behavior of Technetium - Iron Alloy Materials. LA-UR-12-25629, Los Alamos National Laboratory, Los Alamos, NM. 
Korneyko YI, VM Garbuzov, OV Schmidt, and BE Burakov. 2009. Mat. Res. Soc. Symp. Proc. Scientific Basis for Nuclear Waste Management XXXIII, 1193:33-37.

Korneyko YI, SN Britvin, BE Burakov, A Lotnyk, L Kienle, W Depmeier, and SV Krivovichev. 2012. Crystalline Titanate Ceramic for Immobilization of Tc-99. Mat. Res. Soc. Symp. Proc. Scientific Basis for Nuclear Waste Management XXXV, 1475:185-190.

Langton CA. 1988. Challenging Applications for Hydrated and Chemical Reacted Ceramics. DP-MS-88-163, presentation given at American Ceramic Society Meeting, Sydney, Australia, July 12, 1988.

Langton CA and PM Almond. 2013. Cast Stone Oxidation Front Evaluation:Preliminary Results for Samples Exposed to Moist Air. SRNL-STI-2013-00541, Savannah River National Laboratory, Aiken, SC.

Lawrence WE, DL Blanchard, and DE Kurath. 1997. Electrochemical Reduction Removal of Technetium-99 from Hanford Tank Wastes. PNNL-11696, UC-2030, September 1997.

Lee WE, MI Ojovan, and CM Jantzen. 2013. Radioactive waste management and contaminated site clean-up: Processes, technologies and international experience. Woodhead, Cambridge, $924 \mathrm{p}$. www.woodheadpublishing.com/9780857094353.

Lockrem LL. 2005. Hanford Containerized Cast Stone Facility Task 1-Process Testing and Development Final Report. RPP-RPT-26742 Revision 0, CH2M Hill Hanford Group, Inc., Richland, WA.

Lukens WW, JJ Bucher, DK Shuh, and NM Edelstein. 2005. Evolution of Technetium Speciation in Reducing Grout. Environmental Science \& Technology 39:8064-8070.

Lukens, JP Fitts, CM Jantzen, and G Tang. 2014. "Experimental determination of the speciation, partitioning, and release of perrhenate as a chemical surrogate for pertechnetate from a sodalite-bearing multiphase ceramic waste form." Applied Geochemistry 42:47-59.

Lutze W and RC Ewing. 1988. Radioactive Waste Forms for the Future. North-Holland Physics Publishing, New York, NY.

Mattigod SV, B Peter McGrail, DE McCready, L-Q Wang, KE Parker, and JS Young. 2006. "Synthesis and Structure of Perrhenate Sodalite.” Microporous and Mesoporous Materials 91:139-144.

Mattigod SV and JH Westsik, Jr. 2011a. Secondary Waste Form Down-Selection Data PackageDuraLith. PNNL-20718, Pacific Northwest National Laboratory, Richland, WA.

May T, KS Matlack, IS Muller, IL Pegg, and I Joseph. 2010. Improved Technetium Retention in Hanford LAW Glass - Phase 1 Final Report. RPP-RPT-45887, Rev 0, Washington River Protection Solutions, LLC, Richland, WA.

May TH and RA Robbins. 2013. Submerged Bed Scrubber Condensate Technetium Removal and Disposal Pre-Conceptual Engineering Study. RPP-RPT-55213, Washington River Protection Solutions, Richland, WA. 
McCabe DJ, MR Poirier, and DT Hobbs. 2012. Technetium Removal Technology Down-Selection Data Package. SRNL-STI-2012-00476, Savannah River National Laboratory, Aiken, SC.

McDeavitt SM, DP Abraham, and JY Park. 1998. "Evaluation of stainless steel-zirconium alloys as high-level nuclear waste forms." Journal of Nuclear Materials 257:21-34.

McGrail BP, WL Ebert, AJ Bakel, and DK Peeler. 1997. "Measurement of Kinetic Rate Law Parameters on a Na-Ca-Al Borosilicate Glass for Low-Activity Waste." Journal of Nuclear Materials 249(2-3):175-189.

McGrail BP, JP Icenhower, PF Martin, DR Rector, HT Schaef, EA. Rodriguez, and JL Steele. 2000. Low-Activity Waste Glass Studies: FY2000 Summary Report. PNNL-13381, Pacific Northwest National Laboratory, Richland, WA.

McGrail BP, PF Martin, CW Lindenmeier, and HT Schaef. 2001. "Application of the Pressurized Unsaturated Flow (PUF) Test for Accelerated Ageing of Waste Forms." Ageing Studies and Lifetime Extension of Materials. pp 313-320.

Morss LR, MA Lewis, MK Richman, D Lexa. 2000. Cerium, uranium, and plutonium behavior in glass-bonded sodalite, a ceramic nuclear waste form. J. Alloys Comp. 303:42-48.

Muller O, WB White, and R Roy. 1964. "Crystal chemistry of some technetium-containing oxides." J. Inorg. Nucl. Chem., 26:2075-2086.

Navrotsky A, L Mazeina, and J Majzlan. 2008. "Size-driven Structural and Thermodynamic Complexity in Iron Oxides. Science 319:1635-1638. doi: 10.1126/science.1148614.

Neeway JJ, NP Qafoku, BD Williams, Snyder, CF Brown, C Jantzen, and EM Pierce. 2014a. "Dilute Solution Dissolution Kinetics of the Multi-Phase Fluidized Bed Steam Reforming and Bench-Scale Reformer Products and Evidence of Technetium Incorporation in the Sodalite Interstices." Applied Geochemistry, submitted.

Neeway JJ, NP Qafoku, BD Williams, KA Rod, ME Bowden, CF Brown, and EM Pierce. 2014b. "Performance of the fluidized bed steam reforming product under hydraulically unsaturated conditions." Journal of Environmental Radioactivity 131:119-128. http://dx.doi.org/10.1016/j.jenvrad.2013.10.008.

NRC-National Research Council. 2011. Waste Forms Technology and Performance. The National Academies Press, Washington, D.C.

Ojovan MI and WE Lee. 2005. An Introduction to Nuclear Waste Immobilisation. Elsevier, Amsterdam.

Ojovan MI. 2011. Handbook of advanced radioactive waste conditioning technologies. Woodhead Publishing Limited, Cambridge, UK.

Olson AL, NR Soelberg, DW Marshall, and GL Anderson. 2004. Fluidized Bed Steam Reforming of Hanford LAW Using THOR Mineralizing Technology. INEEL/EXT-04-02492, Bechtel BWXT Idaho. 
O'Kelly GD. 1987. Solubility Issues Related to the Performance of a High-Level Nuclear Waste Repository in Bedded Salt: A Survey of Data Needs for Solubilities and Aqueous Species of Technetium, Radium, and Iodine. ORNL/TM-10510, Oak Ridge National Laboratory, Oak Ridge, TN.

Pareizs JM, CM Jantzen, and TH Lorier. 2005. Durability Testing of Fluidized Bed Steam Reformer (FBSR) Waste Forms for High Sodium Wastes at Hanford and Idaho (U). Savannah River National Laboratory, Aiken, SC.

Peretyazhko T, JM Zachara, SM Heald, B-H Jeon, RK Kukkadapu, C Liu, DA Moore, and CT Resch. 2008. "Heterogeneous Reduction of Tc(VII) by Fe(II) at the Solid-Water Interface." Geochimica et Cosmochimica Acta 72:1521-1539. doi: 10.1016/j.gca.2008.01.004.

Phillips JD and LJ Vandeperre. 2010. "Designing wasteforms for technetium: anion capture with layered double hydroxides." In DIAMOND'10 Conference, Decommissioning, Immobilisation and Management of Nuclear Waste for Disposal, Manchester, UK.

Piepel GF, SK Cooley, IS Muller, H Gan, I Joseph, and IL Pegg. 2007. ILAW PCT, VHT, Viscosity, and Electrical Conductivity Model Development. VSL-07R1240-4, Rev. 0, Vitreous State Laboratory, The Catholic University of America, Washington, D.C.

Pierce EM, BP McGrail, EA Rodriguez, HT Schaef, KP Saripalli, RJ Serne, KM Krupk, PF Martin, SR Baum, KN Geiszler, LR Reed, and WJ Shaw. 2004. Waste Form Release Data Package for the 2005 Integrated Disposal Facility Performance Assessment. PNNL-14805, Pacific Northwest National Laboratory, Richland, WA.

Pierce EM, SV Mattigod, RJ Serne, JP Icenhower, RD Scheele, W Um, N Qafoku, and JH Westsik, Jr. 2010. Review of Potential Candidate Stabilization Technologies for Liquid and Solid Secondary Waste Streams. PNNL-19122, Pacific Northwest National Laboratory, Richland, WA.

Pierce EM, DH Bacon, SN Kerisit, CF Windisch, KJ Cantrell, MM Valenta, and SD Burton. 2011. Integrated Disposal Facility FY2011 Glass Testing Summary Report. PNNL-20781, Pacific Northwest National Laboratory, Richland, WA.

Pierce EM, WW Lukens, JP Fitts, CM Jantzen, and G Tang. 2014. Experimental determination of the speciation, partitioning and release of perrhenate as a chemical surrogate for pertechnetate from a sodalite-bearing multiphase ceramic waste form. Applied Geochemistry 42:47-59.

Pires RP, JH Westsik, Jr., RJ Serne, SV Mattigod, EC Golovich, MM Valenta, and KE Parker. 2011. Secondary Waste Form Screening Test Results-THOR ${ }^{\circledR}$ Fluidized Bed Steam Reforming Product in a Geopolymer Matrix. PNNL-20551, Pacific Northwest National Laboratory, Richland, WA.

Qafoku N, JH Westsik, Jr., DM Strachan, MM Valenta, and RP Pires. 2011. Secondary Waste Form Down-Selection Data Package - Fluidized Bed Steam Reforming Waste Form. PNNL-20704, Pacific Northwest National Laboratory, Richland, WA.

Rard JA. 1983. Critical Review of the Chemistry and Thermodynamics of Technetium and Some of its Inorganic Compounds and Aqueous Species. UCRL-53440, Lawrence Livermore National Laboratory, Livermore, CA. 
Resource Conservation and Recovery Act (RCRA). 1976. Public Law 94-580, as amended, 42 USC 6901 et seq. and 42 USC 6927(c) et seq.

Richman MK, DT Reed, AJ Kropf, SB Aase, and MA Lewis. 2001. "EXAFS/XANES studies of plutonium-loaded sodalite/glass waste forms." J. Nucl. Mater. 297(3):303-312.

Riley BJ, J Chun, W Um, WC Lepry, J Matyas, MJ Olszta, X Li, K Polychronopoulou, and MG Kanazidis. 2013. "Chalcogen-Based Aerogels as Sorbents for Radionuclide Remediation." Environ. Sci. Technol., 47(13):7540-7547.

Robbins RA and TH May. 2013. Submerged Bed Scrubber Condensate Technetium Removal and Disposal Preconceptual Engineering Study. RPP-RPT-55213, Washington River Protection Solutions, Richland, WA.

Roberts KA and DI Kaplan. 2009. Reduction Capacity of Saltstone and Saltstone Components. SRNL-STI-2009-00637 Revision 0, Savannah River National Laboratory, Aiken, SC.

Rohatgi A and D Strachan. 2011. An Initial Assessment of Potential Production Technologies for Epsilon-Metal Waste Forms. PNNL-20313, Pacific Northwest National Laboratory, Richland, WA.

Russell RL, MJ Schweiger, JH Westsik, Jr., PR Hrma, DE Smith, AB Gallegos, MR Telander, and SG Pitman. 2006. Low Temperature Waste Immobilization Testing. PNNL-16052, Rev. 1, Pacific Northwest National Laboratory, Richland, WA.

Russell RM. 2013. Supplemental LAW Immobilization Technetium Pre Conceptual Engineering Study. RPP-RPT-55855, Washington River Protection Solutions, Richland, WA.

Ryan K, JB Mason, B Evans, V Vora, and AL Olson. 2008. Steam Reforming Technology Demonstration for Conversion of DOE Sodium-Bearing Tank Waste at Idaho National Laboratory into a Leach-Resistant Alkali Aluminosilicate Waste Form. WM2008 Conference, Phoenix, AZ.

Serne RJ and JH Westsik, Jr. 2011. Data Package for Secondary Waste Form Down-Selection-Cast Stone. PNNL-20706, Pacific Northwest National Laboratory, Richland, WA.

Serne RJ and BM Rapko. 2014. Technetium Inventory, Distribution, and Speciation in Hanford Tanks. PNNL-23319, Pacific Northwest National Laboratory, Richland, WA.

Serrano J, H Gonzalez, H Lopez, N Aranda, F Granados, and S Bulbulian. 2005. "Sorption of ${ }^{99} \mathrm{Mo}_{4}{ }^{2-}$ ions on commercial hydrotalcites." Radiochimica Acta 93:605-609.

Sevigny GJ, ML Kimura, CM Fischer, MJ Schweiger, and D. Kim. 2012. Iron Phosphate Glass Containing Hanford Waste Simulant. PNNL-20670, Rev. 1 (EMSP-RPT-005, Rev. 1), Pacific Northwest National Laboratory, Richland, WA.

Shannon RD. 1976. "Revised Effective Ionic Radii and Systematic Studies of Interatomic Distances in Halides and Chacogenides." Acta Cryst. A32:751-767. 
Singh D, SY Jeong, K Dwyer, and T Abesadze. 2000. "Ceramicrete: A Novel Ceramic Packaging System for Spent-Fuel Transport and Storage." Proceedings of Waste Management $2 K$ Conference, Tucson, AZ, February 27-March 2, 2000.

Singh D, VR Mandalika, SJ Parulekar, and AS Wagh. 2006. "Magnesium Potassium Phosphate Ceramic for ${ }^{99}$ Tc Immobilization.” Journal of Nuclear Materials 348:272-282.

Singh D, R Ganga, J Gaviria, and Y Ysufoglu. 2011. Secondary Waste Form Testing: Ceramicrete Phosphate Bonded Ceramics. ANL-11/16, Argonne National Laboratory, Argonne, IL.

Skomurski FN, KM Rosso, KM Krupka, and BP McGrail. 2010. "Technetium Incorporation into Hematite (alpha- $\mathrm{Fe}_{2} \mathrm{O}_{3}$ ).” Environmental Science \& Technology 44:5855-5861. doi: 10.1021/es100069x.

Smith RW and JC Walton. 1993. "The Role of Oxygen Diffusion in the Release of Technetium from Reducing Cementitious Waste Forms." In: Materials Research Society Symposium Proceedings 294:247-253. Materials Research Society, Pittsburgh, PA.

Soderquist CZ, MJ Schweiger, D Kim, WW Lukens, and JS McCloy. 2014. "Redox-dependent solubility of technetium in low activity waste glass." Journal of Nuclear Materials 449, 173-180.

Srdanov VI, WTA Harrison, TE Gier, GD Stucky, A Popitsch, K Gatterer, D Markgraber, and HP Fritzer. 1994. "Structure and Spectroscopy of Sodalite Containing MnO4- Ions." J. Phys. Chem. B 98:4673.

Strachan DM and TL Croak. 2000. "Compositional Effects on Long-term Dissolution of Borosilicate Glass.” Journal of Non-Crystalline Solids 272:22-33.

Strachan DM, JV Crum, EC Buck, BJ Riley, and MR Zumhoff. 2010. Fiscal Year 2010 Summary Report on the Epsilon-Metal Phase as a Waste Form for ${ }^{99}$ Tc, PNNL-19828, Pacific Northwest National Laboratory, Richland, WA 99352.

Tang M, P Fuierer, P Dickens, and E Fu. 2013. "Irradiation study on $\mathrm{Sr}_{\mathrm{n}+1} \mathrm{Ti}_{\mathrm{n}} \mathrm{O}_{3 \mathrm{n}+1}$ Ruddlesden-Popper phases synthesized by hot-forging." Phys. Status Solidi C 10(2):216-220. doi:10.1002/pssc.201200523.

Taylor HFW. 1997. Cement Chemistry, Thomas Tedford Publishing, London.

Thomson BM, CL Smith, RD Busch, MD Siegel, and C Baldwin. 2003. "Removal of metals and radionuclides using apatite and other natural sorbents." Journal of Environmental Engineering-ASCE, 129(6):492-499.

TTT. 2009. Report for treating Hanford LAW and WTP SW simulants: Pilot Plant Flowsheet. April 2009 THOR Treatment Technologies, LLC, Denver, CO.

Um W, RJ Serne, SB Yabusaki, and T Owen. 2005. "Enhanced Radionuclide Immobilization and Flow Path Modifications by Dissolution and Secondary Precipitates." Journal of Environmental Quality 34(4):1404-1414. 
Um W, H Chang, JP Icenhower, N Qafoku, SC Smith, RJ Serne, EC Buck, RK Kukkadapu, ME Bowden, JH Westsik, Jr., and WW Lukens. 2010. Immobilization and Limited Reoxidation of Technetium-99 by Fe(II)-Goethite. PNNL-19833, Pacific Northwest National Laboratory, Richland, WA. | Full Publication (pdf) |

Um W, HS Chang, JP Icenhower, WW Lukens, RJ Serne, N Qafoku, JH Westsik, Jr., EC Buck, and SC Steven. 2011a. "Immobilization of 99-Technetium (VII) by Fe(II)-Goethite and Limited Reoxidation.” Environmental Science \& Technology 45(11):4904-4913. doi:10.1021/es104343p.

Um W, MM Valenta, CW Chung, J Yang, MH Engelhard, RJ Serne, KE Parker, G Wang, KJ Cantrell, and JH Westsik, Jr. 2011b. Radionuclide Retention Mechanisms in Secondary Waste-Form Testing: Phase II. PNNL-20753, Pacific Northwest National Laboratory, Richland, WA.

Um W, HS Chang, JP Icenhower, WW Lukens, RJ Serne, N Qafoku, RK Kukkadapu, and JH Westsik, Jr. 2012. "Iron Oxide Waste Form for Stabilizing 99Tc." Journal of Nuclear Materials 429(1-3):201-209. doi:10.1016/j.jnucmat.2012.06.004.

Um W, G Wang, HB Jung, and RA Peterson. 2013. Technetium Removal Using Tc-Goethite Coprecipitation. PNNL-22967, EMSP-RPT-017, Pacific Northwest National Laboratory, Richland, WA. $\mid \underline{\text { Full Publication (pdf) } \mid}$

Utsunomiya S and RC Ewing. 2006. "The Fate of the Epsilon Phase (Mo-Ru-Pd-Tc-Rh) in the $\mathrm{UO}_{2}$ of the Oklo Natural Fission Reactors." Radiochimica Acta 94:749-53.

Van Iseghem P, M Aetsens, K Lemmens, S Gin, D Deneele, B Grambow, BP McGrail, DM Strachan, G Wicks, and T McMenamin. 2004. "GLAMOR--A Critical Evaluation of the Dissolution Mechanisms of High-level Waste Glasses in Conditions of Relevance for Geological Disposal." In Euradwaste '04: Radioactive Waste Management: Community Policy and Research Initiatives: Proceedings of the Sixth European Commission Conference on the Management and Disposal of Radioactive Waste. C Davies (ed.), March 29-31, Luxembourg. Directorate-General for Research, European Commission, Luxembourg.

Vance ER, KP Hart, RA Day, ML Carter, M Hambley, MG Blackford, and BD Begg. 1997. "Synroc Derivatives for the Hanford Waste Remediation Task." Mat. Res. Soc. Symp. Proc. Scientific Basis for Nuclear Waste Management XX, 465:341-348.

Vance ER, KP Hart, ML Carter, M Hambley, RA Day, and BD Begg. 1998. "Further Studies of Synrock Immobilization of HLW Sludges and Tc for Hanford Tank Wastes Remediation.” Mat. Res. Soc. Symp. Proc. Scientific Basis for Nuclear Waste Management XXI, 506:89-293.

Vernaz EY and JL Dussossoy. 1992. "Current State of Knowledge of Nuclear Waste Glass Corrosion Mechanisms - The Case of R7T7 Glass.” Applied Geochemistry 1:13-22.

Vernaz E, S Gin, C Jegou, and I Ribet. 2001. "Present Understanding of R7T7 Glass Alteration Kinetics and their Impact on Long-term Behavior Modeling." Journal of Nuclear Materials 298:27-36. 
Vienna JD and DS Kim. 2008. Preliminary IHLW Formulation Algorithm Description. 24590-HLW-RPT-RT-05-001, Rev. 0, River Protection Project, Hanford Tank Waste Treatment and Immobilization Plant, Richland, WA.

Vienna JD, A Fluegal, DS Kim, and P Hrma. 2009. Glass Property Data and Models for Estimating High-Level Waste Glass Volume. PNNL-18501, Pacific Northwest National Laboratory, Richland, WA.

Vienna JD, DS Kim, DC Skorski, and J Matyas. 2013. Glass Property Models and Constraints for Estimating the Glass to be Produced at Hanford by Implementing Current Advanced Glass Formulation Efforts. PNNL-22631, Pacific Northwest National Laboratory, Richland, WA.

Wagh AS. 2004. Chemically Bonded Phosphate Ceramics. Elsevier, NY.

Wagh AS and SY Jeong. 2003. "Chemically Bonded Phosphate Ceramics: I, A Dissolution Model of Formation.” Journal of the American Ceramic Society 86(11):1838-1844.

Wagh AS, SY Jeong, and D Singh. 1999. "High Strength Phosphate Cement Using Industrial Byproduct Ashes." Proceedings of the 1st International Engineering Foundation Conference on High Strength Concrete, July 13-18, 1997, Kona, HI.

Werme LO, IK Bjorner, G Bart, HU Zwicky, B Grambow, W Lutze, RC Ewing, and C Magrabi. 1990. "Chemical corrosion of highly radioactive borosilicate nuclear waste glass under simulated repository conditions." Journal of Materials Research 5(5):1130-1146.

Westphal BR, SM Frank, WM McCartin, DG Cummings, JJ Giglio, TP O’Holleran, PH Hahn, TS Yoo, KC Marsden, KJ Bateman, and MN Patterson. 2013. "Characterization of Irradiated Metal Waste from the Pyrometallurgical Treatment of Used EBR-II Fuel." Metallurgical and Materials Transactions A, November 2013. DOI 10.1007/s11661-013-2114-z.

Westsik Jr. JH, W Um, N Qafoku, GB Josephson, and R J Serne. 2011. "Capture and Immobilization of Technetium from Liquid Radioactive Waste Streams into a Stable Goethite Mineral Form-11351." WM2011 Conference, February 27-March 3, 2011, Phoenix, AZ.

Westsik Jr. JH, GF Piepel, MJ Lindberg, PG Heasler, TM Mercier, RL Russell, AD Cozzi, WE Daniel, RE Eibling, EK Hansen, MR Reigal, and DJ Swanberg. 2013 . Supplemental Immobilization of Hanford Low-Activity Waste: Cast Stone Screening Tests. PNNL-22747, SRNL-STI-2013-00465, Rev. 0, Pacific Northwest National Laboratory, Richland, WA, and Savannah River National Laboratory, Aiken, SC.

Williams BD, JJ Neeway, MM Valenta, ME Bowden, JE Amonette, BW Arey, EM Pierce, CF Brown, and NP Qafoku. 2014. Characterization of Fluidized Bed Steam Reformer (FBSR) and Bench Scale Reformer (BSR) Products in Support of Hanford Supplemental Low Activity Waste (LAW) Vitrification. Journal of Hazardous Materials, submitted.

Xu K, P Hrma, W Um, and J Heo. 2013. "Iron phosphate glass for immobilization of ${ }^{99}$ Tc." Journal of Nuclear Materials 441:262-266.

Yang H, R Lu, RT Downs, and G Costin. 2006. "Goethite, $\alpha-\mathrm{FeO}(\mathrm{OH})$, from single-crystal data." Acta Crystallographica Section E, E62:250-252. 
Zachara JM, SM Heald, B-H Jeon, RK Kukkadapu, CX Liu, JP McKinley, AC Dohnalkova, and DA Moore. 2007. "Reduction of pertechnetate [Tc(VII)] by aqueous $\mathrm{Fe}(\mathrm{II})$ and the nature of solid phase redox products." Geochimica et Cosmochimica Acta 71:2137-2157. 
PNNL-23329

EMSP-RPT-023

\section{Distribution}

No. of

Copies

3 U.S. Department of Energy

Office of Environmental Management

NP Machara

JA Poppiti

SP Schneider

4 U.S. Department of Energy

Office of River Protection

JA Diediker

RA Gilbert

CC Harrington

SH Pfaff

3 Washington River Protection Solutions

WG Ramsey

RA Robbins

KH Subramanian

DJ Swanberg
No. of

Copies

8 Pacific Northwest National Laboratory

CF Brown

KJ Cantrell

RA Peterson

NP Qafoku

S Schlahta

RJ Serne

JD Vienna

DM Wellman

JH Westsik, Jr.

Distr. 1 


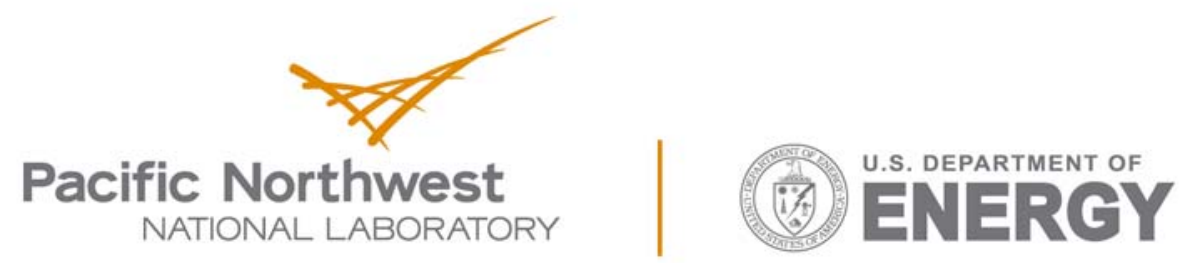

Proudly Operated by Battelle Since 1965

902 Battelle Boulevard

P.O. Box 999

Richland, WA 99352

1-888-375-PNNL (7665)

www.pnnl.gov 